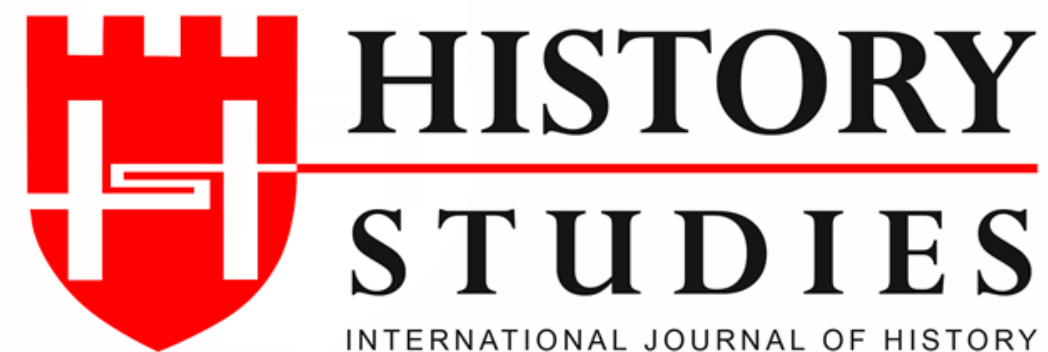

ISSN: 13094173 / (Online) 1309 - 4688 (Print)

Volume: 13, Issue: 4, August 2021

www.historystudies.net

\title{
XVIII. YÜZYILIN IKINNCI YARISINDA TORTUM KAZASI
}

\section{The Tortum District in the Second Half of the 18th Century}

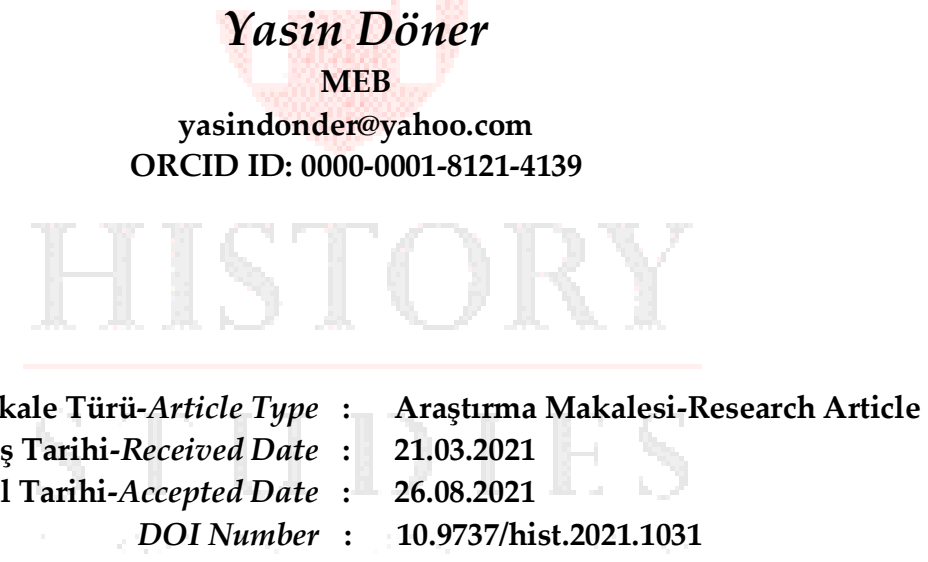

Atıf-Citation:

Yasin Döner, “XVIII. Yüzyılın İkinci Yarısında Tortum Kazası", History Studies, 13/4, Ağustos 2021, s. 1185-1203. 

HISTORY STUDIES

Uluslararası Tarih Araştırmaları Dergisi International Journal of History 13/4, Ağustos - August 2021

1185-1203

Araştırma Makalesi

\title{
XVIII. YÜZYILIN İKİNCI YARISINDA TORTUM KAZASI
}

\author{
The Tortum District in the Second Half of the 18th Century
}

\section{Yasin Döner}

Öz

Osmanlı devlet idaresinde makro dengelerde yaşanan aksaklıklar etkilerini merkezden taşraya doğru zamansal farklılıklara rağmen, sürekli bir akış içerisinde hissettirmiştir. Taşranın merkeze benzeşmesi olarak tanımlanabilecek bu durum modern dünyada metropol şehirlerde yaşanan olumsuzlukların bir süre sonra en ücra kırsal yerleşimlere kadar ulaşması gibidir. Toplumdevlet ilişkisi, birey-devlet ilişkisi, bireyler arası ilişki, memur-devlet ilişkisi vb. pek çok formel ve informel sosyal temas alanlarında yaşanan çatışmalar genel işleyişin çıktıları olarak değerlendirilebilir. $\mathrm{Bu}$ doğrultuda Tortum kazasından Divan-1 Hümayun'a yansıyan şikayetler dönemin aydınlatılması hususunda bir takım ip uçları sağlamaktadır. Yerelde ilk başvuru mercii olarak addedilebilecek şeriyye mahkemelerinde halledilemeyen meseleler merkezi idareye şikâyet yoluyla ulaştırılmıştır. Divanda ele alınan bu şikayetler hususunda verilen hükümler Ahkam Defterleri'ne kaydedilerek bir nüshası da vali, kadı gibi yerel idarecilere gönderilmiştir. Bu çalışmada söz konusu hükümlerden yola çıkarak 1743-1804 yılları arasında Tortum kazasinda timara müdahale, vergi anlaşmazlıkları, eşkıyalık, su, koru ve yayla anlaşmazlıkları, miras vb. alanlarda yaşanan olumsuzluklar ve çözüm yolları değerlendirilmiştir.

Anahtar Kelimeler: Osmanl1, Tortum, Timar, Erzurum, Ahkam Defterleri.

\begin{abstract}
The disruptions in macro balances in the Ottoman state administration made their effects feltin a continuous flow despite the temporal differences from the center to he provinces. This Situation, Which can be defined as the resemblance of the provinces to the center, is like the negativities experienced in metropolitan cities in the modern world reacing the most remote rural settlements after a while. Society-state relationship, individualstate relationship, interpersonal relationship, civil servant state relationship with ect. the conflicts experienced in many formal an informal social contact areas can be evaluated as the outcomes of the general functioning. Accordingly, the complaintsreflected on the Divan-1 Hümayun due to the Tortum district provide some hints for enlightening the period. Issues that could not be settled in the courts of law, which could be considered as the first appeal authority at he local level, were submitted to the central administration by complaint. In This Study, based on the aforementioned provisions, the negativities experienced in Tortum district between 1743-184, such as intervention in the timar lands, tax disputes, banditry, water, grove and plateu dissputes, inheritance and solutions were evaluated.
\end{abstract}

Keywords: Ottoman, Tortum, Timar, Erzurum, Judgement Notebooks 


\title{
Giriş
}

Osmanlı devlet idarecilerinin ve aydınlarının devletin sağlıklı işleyişi noktasında temel referans kaynağı olarak adalet kavramı üzerinde birleştikleri görülmektedir. Bu hususta halkın refahı adına hazırlanıp merkezden yerel idarecilere gönderilen adaletname, kanunname, ferman vb. türü resmi belgelerde temel vurgu reayaya adil davranılması üzerinedir. Merkezi idare bu hassasiyetini kuruluş döneminden itibaren göstermiştir. Bu doğrultuda Karacahisar'ın fethi sonrasında yapılan ilk iş buraya Dursun Fakih'in kadı olarak atanması olmuştur. ${ }^{1}$ Osmanlı taşra idaresinde dirlik ve düzenin yani adaletin sağlanması hususunda başvurulacak ilk merci kadılık makamıdır. Sorunların kadılar eliyle çözümlenememesi durumunda ise en üst mercii olarak halkın sığındığı adalet limanı Divan-1 Hümayun'dur. Divan-1 Hümayun idari ve askeri görevlerinin dışında hukuk sisteminin de en üst basamağında yer almaktaydı. Yerelde sorunlarını çözemeyen halkın doğrudan Divan-1 Hümayun'a başvuru hakkı vardı. Yaşadıkları idari mahalde yer alan mahkemelerde umdukları neticeyi alamayan yahut da yarg1lamayı yapanlara olan itimatsızlıkları nedeniyle davacı kişiler mahkemenin Divan-1 Hümayun'da tekrar görülmesini talep edebiliyordu. ${ }^{2}$

Divan-1 Hümayun'da görüşülen şikayetlere ilişkin alınan kararlar başlangıçta Mühimme Defterleri'ne kaydedilmiştir. 1649 yılından itibaren şikayetlerin sayısında meydana gelen artışla beraber Mühimme Defterleri'ne yalnızca devletin işleyişiyle ilgili konular kaydedilmeye başlanarak halka ait şikayetler, Şikayet Defterleri adı ile düzenlenen defterlere kaydolunmuştur. ${ }^{3}$ 18. yüzyılda yaşanan yoğunluk nedeniyle 1742 'de bir kez daha değişikliğe gidilmiş ve bu tarz konular eyaletlere özel tutulan Ahkam Defterleri'ne kaydedilmeye başlanmıştır. ${ }^{4}$ Şikayet Defterleri'nin devamı niteliğindeki Ahkam Defterleri eyaletler bazında müstakil bir tarzda tutulmuştur. Söz konusu bu defterler Mora (1716) hariç diğer eyaletlerde $1742^{5}$ yılından itibaren tutulmaya başlanmış ve II. Meşrutiyet dönemine kadar da devam etmiştir. Adana, Anadolu, Bosna, Cezayir ve Rakka, Diyarbekir, Erzurum, Halep, İstanbul, Karaman, Maraş, Mora, Özi ve Silistre, Rumeli, Sivas, Şam-1 Şerif, Trabzon bölgelerine ilişkin birbirinden farklı sayılarda olmakla beraber toplam 543 Ahkam Defteri bulunmaktadır. ${ }^{6}$ Bu defterlerde arazi, bağ, bahçe, hane, ağıl ve mera yeri, yaylak-kışlak ve su kullanımı anlaşmazlıkları, alacak-verecek davaları, vergi anlaşmazlıkları, miras, faiz ve esnaf şikayetleri ile ilgili meseleler, vakıf meseleleri, tımar/zeamet ve iltizam ile ilgili problemler gibi șikayet konuları yer almakta olup, Osmanlı Devleti'nin, defterlerin tutulduğu zaman dilimi içerisindeki, tarım, finans, vakıf, ticaret, iç güvenlik, sosyal hayat vb. alanlarındaki yapısı ile kurum, toplum ve birey bağlamında önemli veriler sağlamaktadır. ${ }^{7}$

Bu çalışmada 1742-1804 yılları arasında Erzurum eyaletine bağlı Tortum kazasına ilişkin hükümler değerlendirilecektir. Başbakanlık Osmanlı Arşivi'nde Erzurum eyaletine ait 19 defter yer almaktadır. Bu defterler 1742-1876 tarihleri arasında kaydedilmiş hükümleri içermektedir. Defterlerde Erzurum'a bağlı Bayezid, Erzincan ve Hınıs sancakları ile Bayezid, Diyadin, Eleşkird, İntab (Tutak), Patnos, Sebki, Hamur, Kara Kilise, Erzincan, Kemah, Kuruçay, Kuzican,

\footnotetext{
${ }^{1}$ Süleyman Demir, “Osmanlı' da Kadılar ve Naipler”, Uluslar arası Sosyal Bilimler Dergisi, C. 1, S. 1, 2017, s. 29.

${ }^{2}$ Recep Ahıshalı, "Divan-1 Hümayun Teşkilatı”, Osmanlı Ansiklopedisi, C. 6, Ed. Güler Eren, Kemal Çiçek, Cem Oğuz, Yeni Türkiye Yay., Ankara 1999, s. 32. 24-33.

${ }^{3}$ Mübahat Kütükoğlu, "Mühimme Defterleri", TDVIA, C.31, İstanbul 2006, s. 520-521, Feridun Emecen, "Osmanl1 Divanının Ana Defter Serileri: Ahkâm-1 Mîrî, Ahkâm-1 Kuyûd-1 Mühimme ve Ahkâm-1 Şikâyet”, TALID, C. 3, S. 5, 2005, s. 110.

${ }^{4}$ Ramazan Günay, "Osmanlı Arşiv Kaynakları İçerisinde Ahkam Defterleri: Gelişim Seyri, Mutevası ve Önemi”, Süleyman Demirel Üniversitesi Sosyal Bilimler Dergisi, S. 11, 2013, s. 13.

${ }^{5}$ Halil Sahillioğlu, “Ahkam Defteri”, TDVIA, C. 1, İstanbul 1988, s. 550.

${ }^{6}$ Başbakanlık Osmanlı Arşivi Rehberi, haz. Yusuf İhsan Genç, Mustafa Küçük vd., Devlet Arşivleri Genel Müdürlüğü Osmanlı Arşivleri Daire Başkanlığı Yayın Nu: 108, Başbakanlık Basımevi, İstanbul 2010, s. 22-41.

${ }^{7}$ Emecen, a.g.m., s. 134, Günay, a.g.m., s. 21-22.
}

\author{
History Studies \\ www.historystudies.net
}


Refahiye, Bayburt, İspir, Keskim, Kiğı, Pasinler, Tercan, Namarvan, Hınıs ve Tortum kazalarına ait kayıtlar bulunmaktadır. ${ }^{8}$ İlk 10 defterin tarandığı bu çalışmada Tortum kazasına ilişkin hükümler, 1 numaralı Erzurum Ahkam Defteri (6 adet), 3 numaralı Erzurum Ahkam Defteri (10 adet), 4 numaralı Erzurum Ahkam Defteri (4 adet), 6 numaralı Erzurum Ahkam Defteri (3 adet), 9 numaralı Erzurum Ahkam defteri (2 adet) olmak üzere toplam 25 tanedir.

Tortum Kanuni Sultan Süleyman zamanında 1549 Gürcistan seferi sonucunda kesin olarak ele geçirilerek Erzurum Beylerbeyliği’ne bağlı bir sancak haline getirilmiştir. 17. yüzyılın ortalarına kadar da bu statüsünü devam ettirmiştir. ${ }^{9}$ 18. Yüzyılın ikinci yarısına ait Ahkam Defterleri kayıtlarında Tortum Erzurum'a bağlı bir kaza statüsündedir. ${ }^{10} 19$. yüzyılın başlarında yeniden Erzurum'a bağlı bir sancak olarak görülen Tortum zaman zaman İspir veya Bayburd'a bağlı kaza ve nahiye statüsüne girse de 1879 vilayet nizamnamesine göre Erzurum'a bağlı bir kaza haline getirilmiştir ki bu idari yapısı yüzyılın sonuna kadar devam etmiştir. ${ }^{11}$

Literatürde Ahkam defterlerine dayalı Tortum'u konu edinen herhangi bir çalışma bulunmamaktadır. Erzurum Ahkam Defterleri'ne ilişkin çeşitli tez ve makaleler yer almakla beraber müstakil olarak Tortum ele alınmamıştır. Söz konusu bu çalışmada Tortum kazasına ilişkin şikayetler kategorik biçimde ele alınarak değerlendirilecektir.

\section{1.Çözüme Yönelik Başvuru Kaynakları}

Tortum kazasından merkeze yapılan şikayetler Divan-1 Hümayun'da görüşülerek çözüme yönelik hükümler Ahkam defterlerine yazılmıştır. Ancak bu hükümler çıkarılırken merkezde önemli veri kaynakları kullanılmaktaydı. Defterlerdeki kayıtlar incelendiğinde bazı ifadeler göze çarpmakta ve bu veri kaynakları hakkında ipucu sağlamaktadır. Geçmiş dönemlere ilişkin Divan1 Hümayun'da tutulan defterler şikâyet konularına bağlı olarak yeniden tetkik ediliyor ve devletin hafızası niteliğindeki bu kayıtlar referans alınarak yaşanan sorunlara çözüm getiriliyordu. Kayıtlarda yer alan "...defterhâne-i âmiremde mahfûz olan..." ", "...hazine-i amiremde mahfuz bulunan..."13, “...defter-i hakanide mestur olduğu..."14 tarzındaki ifadeler defterlerin defterhanede ${ }^{15}$ muhafaza edilerek gerektiğinde müracaat edildiğini göstermektedir. Genel itibariyle timar/zeamet, tevcihat ve vergiler hususunda tutulan defterlere başvurulmuştur. "...defterhâne-i âmiremde mahfûz olan ruznamçe-i hümayunuma müracaat olundukda..." ifadesi ile Timar Ruznamçe Defteri'ne, “...liva-i mezkurun defter-i mufassall..." 17 ifadesinde Mufassal Tahrir Defteri'ne, “...defter-i cedid-i hakanide maktu' yazılmağla..." ${ }^{\prime \prime}$, kaydında en son tutulan Tahrir Defteri'ne, “...klşlağın resimleri defter-i vakf-ı mezbura hasıl yazılmağla ... "19 vakıf defterine, “...defter-i icmalde kurra-i ahir ile bir görülüb...” ifadesinde ise İcmal Tahrir Defterleri'ne başvurularak kayıtların incelendiği ve ona göre hüküm verildiği tespit edilmektedir. Adı geçen defterlere başvurularak önceki kayıtlar doğrultusunda hüküm yazılmış olduğu, “...vech-i meşrûh üzere oldı̆̆ı mestûr ve mukayyed bulunmağın defter-i hâkânî ve kânûn üzere

\footnotetext{
${ }^{8}$ Başbakanlık Osmanlı Arşivi Rehberi, haz. Yusuf İhsan Genç, Mustafa Küçük vd., Devlet Arşivleri Genel Müdürlüğü Osmanlı Arșivleri Daire Başkanlığı Yayın Nu: 108, Başbakanlık Basımevi, İstanbul 2010, s. 30.

${ }_{9}^{9}$ Mehmet İnbaşı, Osmanlı İdaresinde Tortum Sancağl (1549-1650), Yeditepe Yayınevi, İstanbul 2008, s. 57.

${ }^{10}$ BOA. A.DVNS.AHK.ER.d. 4: 202/3.

${ }^{11}$ Yunus Özger, "XIX. Yüzyıl'da Tortum’un Nüfus Durumu”, Atatürk Üniversitesi Sosyal Bilimler Enstitüsü Dergisi, C. 8, S. 2, s.115-116 Atatürk Üniversitesi Sosyal Bilimler Enstitüsü Dergisi, C. 8, S. 2, s. 115-116.

12 BOA. A.DVNSAHK.ER.d. 1: 184/4.

${ }^{13}$ BOA. A.DVNSAHK.ER.d. 4: 103/4.

${ }^{14}$ BOA. A.DVNSAHK.ER.d. 3: 211/2.

${ }^{15}$ Erhan Afyoncu, “Defterhane”, TDVIA, C. 9, İstanbul 1994, s. 100-104.

${ }^{16}$ BOA. A.DVNSAHK.ER.d. 3: 47/1.

${ }^{17}$ BOA. A.DVNSAHK.ER.d. 3: 211/2.

${ }^{18}$ BOA. A.DVNSAHK.ER.d. 3: 281/1.

${ }^{19}$ BOA. A.DVNSAHK.ER.d. 4: 202/3.
} 
'amel olunmak..." "20, "...Divan-ı Hümayun kalemine sorulduk da ... mucibince amel oluna ....." “...defter emini Yeğen Mehmed dame mecidühü arz etmeğin ... arz mucibince amel olunmak... "22 gibi ifadelerden anlaşılmaktadır.

\section{2.Şikayet Yöntemi ve Şikayetin Tarafları}

Tortum kazasında ister yöneten isterse yönetilen kesiminden kişiler olsun yerelde sorunlarını halledemediği takdirde Divan-1 Hümayun'a başvurmaktan çekinmemişlerdir. İstanbul'a uzak bir noktada olmasına rağmen adalet arayışlarını merkeze ulaştırmayı başarmışlardır. Bunu yaparken farklı yöntemler izledikleri görülmektedir. İlk yöntem olarak şikayetçi kişilerin bizatihi İstanbul'a gelerek davalarını Divan-1 Hümayun'a taşıdıkları tespit edilmiştir. Tortum halkının bizatihi İstanbul'a gelerek şikâyetlerini gerçekleştirdiği defterlerdeki “ ...südde-i saadetime gelüb...” ifadesiyle tamamlanan kayıtlardan anlaşılmaktadır. ${ }^{23}$ İncelenen dönem içerisinde 15 şikayetin bu tarzda yapıldığı tespit edilmiştir. Bu sayı toplam şikayetler içerisinde \%60'lık bir orana tekabül etmektedir. Şikâyet oranının artışıyla paralel olarak sistemin hantallaşması şikâyeti yapanların uzun süre başvuru sonucunu beklemesine bu zaman zarfında da türlü sıkıntılar yaşamalarına neden olmaktaydı. ${ }^{24}$ Tüm bu sıkıntılara rağmen Tortum gibi merkeze uzak bir kazadan insanların türlü sıkıntıları göze alarak İstanbul'a geliyor olması sorunlarının çözümünü elden takip etmeyi hızlı ve daha güvenilir bulmalarından kaynaklanmış olsa gerektir. Şikâyet yöntemlerinden ikincisi "... südde-i sa'adetime arzuhâl idüb..." 25 , “...rikab-ı hümayunuma arzuhâl sunub..." "26, "rikabhümayunuma arzuhal idüb..."27, ya da “...Züemadan Ebubekir zîde kadruhû arzuhâl idüb ..."28 ifadelerinin örneklendirdiği üzere arzuhal/dilekçe ile başvuru şeklindedir. Arzuhal ile başvurular (8 adet) toplam şikayetlerin \%32'sini oluşturmaktadır. Üçüncü başvuru şekli arzuhal ile müracaatın bir diğer formu olarak da değerlendirilebilecek olan mahzar yazmak usulüdür. Mahzar bugünkü anlamda birçok kişinin toplu şekilde dilekçe ile şikâyetlerini ifade etmesi şeklinde açıklanabilir. ${ }^{29}$ Tortum kazasına ilişkin hükümler içerisinde yer alan “...züema ve erbab-ı timarları südde-i saadetime mahzar gönderüb... "30 ifadesi bu tarz başvurulara örnektir. Örnekte görüldüğü üzere şikâyette bulunan kişiler zeamet ve timar sahipleridir. Şikâyet konusunu ortak bir dilekçe ile ifade etmeyi tercih etmişlerdir. Merkeze başvuru yöntemlerinden sonuncusu mektup göndermektir. İncelediğimiz dönemde Tortum'da bu usulle yapılan tek başvuru yer almaktadır. Bahse konu şikâyeti yapan Hemşin kazası naibidir. Resmi görevi sebebiyle bulunduğu yeri terk edememesi ve şikâyetin güvenlik merkezli bir konu olması nedeniyle mektupla başvuruyu tercih etmiş olması muhtemeldir. “...Hemşin kazası naibi Molla Abdusseyid zide ilmühu mektub gönderüb ..."31 ifadesinin yer aldığı hükümde şikâyet konusu eşkıyalık faaliyetleridir.

Ahkam Defterleri'ndeki kayıtlardan yola çıkarak denilebilir ki toplumun her kesimi devletin sunduğu adalet kanallarını kullanma imkanına sahiptir. Bu durumu gösteren bir örnekte yönetilen kesiminden kişiler bizatihi merkeze gelerek hak aramışlardır. Bu meyanda "Osman nam kimesne

\footnotetext{
${ }^{20}$ BOA. A.DVNSAHK.ER.d. 1: 182/1.

${ }^{21}$ BOA. A.DVNSAHK.ER.d. 4: 103/4.

${ }^{22}$ BOA. A.DVNSAHK.ER.d. 3: 211/2.

${ }^{23} \mathrm{Bu}$ konuda Tortum kazası halkının bireysel veya toplu şekilde merkeze gelerek şikayetlerini ulaştırdıkları dönemin kayıtlarında görmek mümkündür. Bkz. BOA. A.DVNSAHK.ER.d.1: 49/1, BOA. A.DVNSAHK.ER.d.1: 148/5, BOA. A.DVNSAHK.ER.d.1: 285/4.

${ }^{24}$ Feridun M. Emecen, a.g.m., s. 131.

${ }^{25}$ BOA. A.DVNS.AHK.ER.d. 3: 250/2, BOA. A.DVNS.AHK.ER.d. 4: 44/1, BOA. A.DVNSAHK.ER.d. 4: 103/4.

${ }^{26}$ BOA. A.DVNS.AHK.ER.d. 3: 305/1.

${ }^{27}$ BOA. A.DVNSAHK.ER.d.3: 251/1.

${ }^{28}$ BOA. A.DVNS.AHK.ER.d. 1: 168/2, BOA. A.DVNSAHK.ER.d. 3: 241/2.

${ }^{29}$ Mehmet Zeki Pakalın, "Mahzar”, Tarih Deyimleri Ve Terimleri Sözlüğü, MEB Yayınevi, C. 2, İstanbul 1993, s. 391.

${ }^{30}$ BOA. A.DVNSAHK.ER.d. 3: 211/2.

${ }^{31}$ BOA. A.DVNS.AHK.ER.d. 4: 259/3.
} 
gelüb..."32 ifadesinden reaya kesiminden bir başvurunun yapıldığg görülmektedir. Timar sisteminin uygulandığı bir bölge olması nedeniyle en sık şikayetçi olan kesimin timar/zeamet sahipleri olduğu görülmektedir. İncelenen dönemde toplam 8 şikayet bu kişiler tarafından yapılmıştır. "Züemadan İbrahim zîde kadruhû gelüb..." "33 ifadesinden anlaşıldığı üzere şikayetçi bir zaimdir. Timar ve zeamet sahipleri dışında yönetici kesimden naib ${ }^{34}$, kağıt emini ${ }^{35}$ ve vakıf mütevellilerinin ${ }^{36}$ şikayetleri de Tortum'a ait Ahkam Defteri kayıtlarında yer bulmuştur. Kayıtlar arasında dikkat çeken bir diğer husus toplu şikayetlerin olmasıdır. Bu durum “...Dürzioğlu Mustafa ve Bulacı Mehmed ve Ahmed ve Ebubekir ve Mustafa nam kimesneler gelüb..." örneğinde beş kişiden oluşan bir grup halinde şikayet olduğu gibi bazen de "...Hinzorik nam karye ahalileri südde-i saadetime arzuhal idüb..." 38 örneğindeki gibi tüm köy halkının şikayeti şeklinde gerçekleşmiştir.

Şikayet edilenler söz konusu olduğunda da benzer toplum kesimlerini görmek mümkündür. Timar/zeamet sahiplerinin genel olarak şikayet ettiği odak timar toprakları üzerinde vergi vermekle yükümlü köy halkıdır. Yahut da beratlı timar topraklarına farklı kişi veya sipahilerin müdahalesi nedeniyle şikayet edilenler mevcuttur. Ehl-i örf geçimini büyük ölçüde vergi verenler üzerinden sağladığı için genel itibariyle şikayetçi oldukları zümre reaya olmuștur. ${ }^{39}$ Madalyonun diğer tarafında reayanın şikayetçi olduğu kișiler ise adaleti tesis etmesini beklediği ama karșılığını zulüm ve baskı olarak gördüğü ehl-i örf taifesi olmuştur. ${ }^{40}$ Ortak kullanım alanları söz konusu olduğunda birbirine yakın köylerin de şikayet edildiği görülmektedir. Örneğin Keğik (Kapıkaya) köyü halkı Norşin (Karlı) köyü ahalisi tarafından su kullanımı nedeniyle şikayet edilmiştir. ${ }^{41}$ Adi suçlar nedeniyle reayadan kişiler şikayet edilmiş̧ir. Genellikle gasp suçuna bağlı olarak bu şahıslar ferdi veya toplu olarak şikayet edilen zümre içerisindedir. Güvenliği tehdit etmeleri nedeniyle yöneticiler veya halk tarafından şikayet edilenler eşkıyalık yapan kişi veya gruplar da söz konusudur. ${ }^{42}$ Tüm bunlar dışında isim verilmeksizin şikayet edilenler de kayıtlara yansımıştır. Yereldeki kadı mahkemesi kayıtlarında ya da resmi diğer kayıtlarda isimleri ve kimlikleri belirli olması muhtemel kișiler için hükümlerde "... karye-i mezbur sipahisi..." kimesne..."44, “ ma'lûmü’l-esâmî kimesneler..."45 tabirleri kullanılmış ve açık kimlikleri verilmemiştir.

\footnotetext{
32 BOA. A.DVNS.AHK.ER.d. 1: 182/1. Benzer şikayetler için bkz. BOA. A.DVNSAHK.ER.d. 6: 53/4, BOA. A.DVNSAHK.ER.d. 9: 156/2, BOA. A.DVNSAHK.ER.d. 1: 285/4.

${ }^{33}$ BOA. A.DVNS.AHK.ER.d. 1: 148/5. Ayrica bkz. BOA. A.DVNSAHK.ER.d. 1: 168/2, BOA. A.DVNS.AHK.ER.d. 1: 184/4, BOA. A.DVNS.AHK.ER.d. 3: 11/3, BOA. A.DVNS.AHK.ER.d.3: 211/2, BOA. A.DVNS.AHK.ER.d. 3: 250/2, BOA. A.DVNS.AHK.ER.d. 6: 53/2, BOA. A.DVNS.AHK.ER.d.6: 53/3.

${ }^{34}$ BOA. A.DVNS.AHK.ER.d. 4: 259/3.

${ }^{35}$ BOA. A.DVNS.AHK.ER.d. 3: 47/1.

36 BOA. A.DVNS.AHK.ER.d. 4: 202/3.

${ }^{37}$ BOA. A.DVNS.AHK.ER.d. 3: 281/1.

${ }^{38}$ BOA. A.DVNS.AHK.ER.d. 4: 103/4.

${ }^{39}$ BOA. A.DVNS.AHK.ER.d. 3: 250/2

${ }^{40}$ BOA. A.DVNSAHK.ER.d. 3: 241/2.

${ }^{41}$ BOA. A.DVNS.AHK.ER.d. 1: 49/1.

${ }^{42}$ BOA. A.DVNS.AHK.ER.d. 3: 305/1.

${ }^{43}$ BOA. A.DVNS.AHK.ER.d. 3: 281/1

${ }^{44}$ BOA. A.DVNS.AHK.ER.d. 1: 168/2.

45 BOA. A.DVNS.AHK.ER.d. 6: 53/3.
} 


\begin{tabular}{|c|c|c|c|c|}
\hline Şikayet Eden & Şikayet Edilen & Tarih & Konu & $\begin{array}{l}\text { Defter- } \\
\text { Hüküm no }\end{array}$ \\
\hline Norşin köyü halk1 & Keğik köyü halkı & 20 Ağustos 1743 & Su Kullanımı & $1-49 / 1$ \\
\hline Zeamet sahibi İbrahim & Tiv köyü halk1 & 22-31 Mayıs 1746 & Vergi & $1-148 / 5$ \\
\hline Zeamet sahibi Ebubekir & İsim verilmemiş & 15-24 Aralık 1746 & Zeamet & $1-168 / 2$ \\
\hline Osman & Osman & 22 Şubat-3 Mart 1747 & Timar & $1-182 / 1$ \\
\hline Zeamet sahibi Ebubekir & $\begin{array}{l}\text { Yeniçeri, İleri gelenler } \\
\text { ve ehl-i örf }\end{array}$ & 4-12 Mart 1747 & Zeamet/vergi & $1-184 / 4$ \\
\hline Mehmed & $\begin{array}{l}\text { Merus? cemaatinden } \\
\text { Abdülhay ve Tahir }\end{array}$ & 7-15Temmuz 1749 & Yayla kullanımı & $1-285 / 4$ \\
\hline Zeamet sahibi İbrahim & Öşk-i Sor köyü halk1 & 28 Şubat-9 Mart 1750 & Vergi & $3-11 / 3$. \\
\hline $\begin{array}{lll}\begin{array}{l}\text { Zeamet } \\
\text { sahipleri }\end{array} & \text { ve } & \text { timar } \\
\end{array}$ & & 9-18 Eylül 1754 & Timar & $3-211 / 2$ \\
\hline Kağıt Emini İbrahim & İs kalesi köyü halk1 & 21-29 Kasım 1750 & Vergi & $3-47 / 1$. \\
\hline $\begin{array}{l}\text { Ahmed ve Mustafa } \\
\text { Kardeşler }\end{array}$ & İsmail Beşe & 28 Ekim-6 Kasım 1754 & Miras & $3-215 / 2$ \\
\hline $\begin{array}{l}\text { Mustafa, Ahmed ve } \\
\text { Sabit }\end{array}$ & Sipahiler & 2-10 Haziran 1755 & Timar/vergi & $3-241 / 2$ \\
\hline Timar sahibi Ebubekir & Reaya & 21-30 Temmuz 1755 & Timar/vergi & $3-250 / 2$. \\
\hline Osman & $\begin{array}{l}\text { Kürt Abbas ve kardeşi } \\
\text { Osman }\end{array}$ & 31Temmuz-8 Ağustos 1755 & Eşkıyalık & $3-251 / 1$ \\
\hline $\begin{array}{l}\text { Musa'nın oğlu Seyyid } \\
\text { Ahmed }\end{array}$ & Tortum halk1 & 15-24 Aral1k 1755 & Zeamet & $3-274 / 4$ \\
\hline $\begin{array}{l}\text { Dürzioğlu Mustafa, } \\
\text { Bulacı } \\
\text { Ahmed, Ebubekir ve } \\
\text { Mustafa }\end{array}$ & Köy sipahisi & 24 Ocak- 1 Şubat 1756 & Vergi & 3- $281 / 1$ \\
\hline Osman & $\begin{array}{l}\text { Bekiroğlu Osman ve } \\
\text { oğlu Ali, Salih, İsmail ve } \\
\text { enişteleri Ali }\end{array}$ & 2-11 Şubat 1756 & Eşkıyalık & 3- 305/1. \\
\hline Ekik köyü halk1 & $\begin{array}{l}\text { Çöre ve Harteniz ve } \\
\text { diğer köylerin halk1 }\end{array}$ & 28 Haziran-6 Temmuz 1758 & Koru davası & $4-44 / 1$. \\
\hline Hinzorik köyü halk1 & Ayan-mütegallibe & 26 Temmuz-4 Ağustos 1759 & Vergi & 4- 103/4. \\
\hline $\begin{array}{l}\text { Vakıf Mütevellileri } \\
\text { Ahmed ve Mustafa }\end{array}$ & $\begin{array}{l}\text { Merdis? aşiretinden } \\
\text { Darbikoğlu Mustafa }\end{array}$ & 13-21 Haziran 1762 & Yaylak Kışlak & $4-202 / 3$ \\
\hline $\begin{array}{l}\text { Hemşin kazas1 naibi } \\
\text { Molla Abdusseyid }\end{array}$ & Eşkıyalar & 13-30 Temmuz 1762 & Eşkıyalık & $4-259 / 3$ \\
\hline Timar sahibi Ömer & Adı bilinen kişiler & 12-21 Aralık 1190 & Timar & $6-53 / 3$ \\
\hline Sipahi Abdullah & Adı bilinen kişiler & 12-21 Aral1k 1190 & Timar & $6-53 / 2$ \\
\hline Yakub & Abdullah & 12-21 Aralık 1190 & Gasp & $6-53 / 4$ \\
\hline $\begin{array}{l}\text { Seyyid Mustafa } \\
\text { Seyyid Hüseyin }\end{array}$ & $\begin{array}{lrr}\text { Lovoğlu } & \text { Hasan } & \text { Beşe, } \\
\text { Kay1oğlu } & \text { Hasan } \\
\text { ve Fatma }\end{array}$ & 6-14 Haziran 1798 & Gasp & 9- 94/2. \\
\hline Sunullah & Osman & 6-14 Haziran 1798 & Timar & $9-156 / 2$ \\
\hline
\end{tabular}

Tablo 1: Hükümlerde Şikayet Eden ve Edilenler 


\title{
3.Tortum Kazasında Yaşanan Sorunlar ve Hukuki Karşılıkları
}

Erzurum Ahkam Defterleri'nde Tortum kazasına ilişkin tespit edilen hükümlerde sosyal, ekonomik ve idari anlamda pek çok sorunun yaşandığı görülmektedir. Dar ölçekli bir idari birim olmasına rağmen bölgede yaşanan hadiseler ve gerilim noktaları devletin bütününde yaşananlardan çok da ayrı değildir. Asıl büyük problem ise yerelde bu sorunların çözümüne ulaşılamamasıdır. Bu nedenle Tortum'da yaşayan köylü, şehirli, tüccar, sipahi, yeniçeri, mütevelli vs. toplumsal kesimler sorunlarını merkeze taşımışlardır.

Ahkam Defterleri yerelde tutulan Şeriyye Defterleri'ne benzeri bir niteliğe sahiptir. Osmanlı Devleti'nin yürütme organı Divan-1 Hümayun'un bir üst mahkeme olarak verdiği hükümler devletin hukuki anlaşmazlıklara yönelik resmi görüşünü ve yereldeki fiili karşılıklarını göstermektedir. Defterlerde adi suçlardan, idari suçlara kadar çeşitli alanlarda şikayetler mevcuttur. $\mathrm{Bu}$ doğrultuda Tortum kazasından merkeze ulaşan şikayetler timar/zeamet topraklarının kullanımı, vergi anlaşmazlıkları, koru, yayla, kışla, arazi ve su kullanımına ilişkin suiistimaller, gasp-eşkıyalık ve miras paylaşımı gibi konuları içermektedir.

\subsection{Timar/zeamet anlaşmazlıkları}

Osmanlı Devleti’nde hizmet karşılığ 1 olarak devlete yararlılığ görülen asker veya memur kişilere yaptıkları göreve karşılık olarak ülkenin belirli bölgelerinden tevcih edilmiş olan vergi kaynaklarına ve özellikle de yıllık geliri 20 bin akçeye kadar olan dirliklere timar denmektedir. ${ }^{46}$ Timar sistemi idari anlamda büyük öneme sahiptir. Öyle ki timar sisteminin uygulandığı eyalette en üst yöneticiden en aşağıda yer alan sipahiye kadar merkezi idarenin bölgede gücünü hissettirdiği bir yapı tesis edilmiştir. ${ }^{47}$

Tarıma dayalı ekonomik yapının geçerli olduğu Osmanlı Devleti'nde ana omurgayı timar sistemi belirlemiştir. Mali, askeri ve idari kollarıyla timar sistemi Osmanlı taşra teşkilatının en işlevsel yönünü oluşturmuştur. Devlet hazinesine her ne kadar direk girdisi olmasa da taşradaki memurların ve yetiştirilen atlı askerlerin finansmanı timar sistemi üzerinden sağlanmıştır. Üretimdeki süreklilik ve reayanın refahı da büyük ölçüde bu sistemin sağl1klı işlemesine bağlı kalmıştır. 17. yüzy1l itibariyle timar sisteminde yaşanan olumsuzluklar arzu edilen vergi ve yeterli asker toplanamamasına, toprağın boş kalmasına ve tarımsal üretimin düşmesine, toprak üzerinde yaşayan halkın ise göç etmesine neden olmuştur. Böylesi bir durum sarmal etkisi yaratmış ve tabandan tavana olumsuzluklar silsilesi yaşanarak toplumun geneline menfi yansımalarla geri dönmüştür. ${ }^{48}$

Erzurum Ahkam Defterleri'ne göre Tortum kazasında timar konusunda yaşanan problemlerin çeşitli vecheleri vardır. Hükümler üzerinden yapılacak değerlendirmeler bu vecheleri ortaya koyacaktır. Örneğin, 2-10 Haziran 1755 tarihli kayıtta Erzurum vilayetine Tortum ve ( ) kadılarına gönderilen hükümde, Mustafa, Ahmed ve Sabit bir arzuhal yazarak merkezi idareye başvurmuşlardır. Buna göre havas-1 hümayundan Erzurum sancağına bağlı Tortum kazasının Heris? mukataası karyelerinden ( ) ve ( ) bulunan yerlerden öşür ve resm-i haslarını adı geçen şahıslar ortak olarak almakta iken sınırları belirli bu yerlerde daha önce herhangi bir ilişkisi olmamasına rağmen yakın çevrede bulunan timar köyleri sipahilerinden iki kişi bölgeye müdahale etmiştir. Sipahilerin iddiasına göre, söz konusu topraklar kendi sahip oldukları timar köyleri toprakları içerisindedir. Buna dayanarak bu alanların öşür ve resmini toplama hakkı da kendilerine aittir. Bu hususta daha önce kanun ve deftere aykırı hareket ettikleri konusunda şer'i mahkemece

\footnotetext{
46 Ömer Lütfü Barkan, “Timar”, TDVİA, C. 12/1, MEB Yayınları, 1979, s. 286.

47 Emine Erdoğan Özünlü, Ayntab Sipahileri/ Bir Osmanlı Sancağında Timarlı Sipahi Olmak (1530-1647), Berikan Yayınevi, Ankara 2011, s. 51.

48 Osman Gümüşçü - Emine Erdoğan Özünlü, "Osmanlı İmparatorluğunda İç Göç Aktörleri Olarak Çift-Bozanlar”, Amme İdaresi Dergisi, C. 49, S. 1, Mart 2016, s. 36-38.
}

\author{
History Studies \\ www.historystudies.net
}


verilen hukuki bir belge olmasına rağmen sipahiler kanunsuz uygulamalarından vazgeçmemişlerdir. Durum incelenerek söz konusu sipahilerin usulsüzlüklerine son verilmesi ve daha önce olduğu gibi bahse konu yerlerin öşür ve resminin şikâyetçi kişiler tarafından alınmasının sağlanması hususunda hüküm yazılmıştır. ${ }^{49}$ Kayıttan anlaşıldığı üzere timar topraklarına dışarıdan başka bir sipahi tarafından müdahale söz konusudur. Devlet idaresi timar topraklarını mümkün olduğunca fazla kişiye paylaştırmak suretiyle bir yandan daha fazla asker temin etmeyi bir yandan da bölgede tekelleşmeyi bir başka ifade ile feodal bir zümrenin ortaya çıkışını önlemeye çalışmıştır. ${ }^{50}$ Ancak bu paylaşım ve parçalı yapı zaman zaman bölgede bulunan timar sahiplerinin güvenlik boşluklarından yararlanarak hak ihlallerine başvurmalarına sebep olmuştur. Merkeze yapılan bu şikâyetten anlaşıldığı üzere şikayet sahipleri önce yerelde haklarını aramayı tercih etmişler ancak yerel mahkemenin kendilerini haklı bulması soruna çözüm getirmeyince İstanbul'a başvurmuşlardır.

21-30 Temmuz 1755 tarihli bir başka kayıtta timar sahiplerinden Ebubekir merkeze gönderdiği arzuhalde belirttiği üzere Tortum sancağı Haho nahiyesine bağlı Otha (Kirazlı) köyünde 18500 akçelik timarın sahibidir. Buna ek olarak Ahcorik nahiyesinde 50000 akçe bedeli olan Dankar (Kırmalı) köyü ve mezrası Şah Kamu 1748 tarihinden bu yana bazı arazilerin ekilmemesi, boş kalması sebebiyle vergileri alınamamış, var olan ürün ve vergiler reayanın zimmetinde kalmıştır. Dolayısıyla timar sahibibahsi geçen köy ve mezrada Defter-i Hakani'ye uygun olarak kimsenin müdahalesi olmaksızın ürün ve vergilerin kendisine verilmesini talep etmiştir. Defterhane-i Amire'de tutulan Ruznamçe Defterleri incelendiğinde şu verilere ulaşılmıştır: Haho nahiyesine tabi 2000 akçe yazarı olan İs köyü, Ahcorik nahiyesine tabi 6000 akçe bedeli olan Dankar köyü, Şah Kamu mezrası ve Haho nahiyesine bağlı Otha köyü ve diğer yerlerden 25600 akçelik olmak üzere 1740/41 tarihinde Kefe canibi Seraskeri vezir Numan Paşa tarafından Ebubekir'e tevcih edilmiş ve buna dayalı olarak da berat verilmiştir. Yine bahsedilen kayıtlarda İs köyünden 2000 akçesi, 5 Ağustos 1742/43 günü mirmirandan Hamza'ya tevcih ve tezkire olunmuştur. Sonuç olarak timar sahibi Ebubekir'in Sultan Mahmud Han zamanında defter ve kanun üzere davranılması hususunda emr-i şerif verildiğini bildirip yenilenmesini istemesinin kanuna uygun olduğu belirlenmiş ve bu doğrultuda işlemlerin yürütülmesi için hüküm yazılmıştır. ${ }^{51}$ Timar tevcihi hususunda yaşanan bir anlaşmazlık nedeniyle Divan-1 Hümayun'a yapılan bu başvuruda şikâyet sahibinin iddiası önceki kayıtlara bakılarak çözümlenmeye çalışılmıştır. Timar tevcihleri noktasında merkezi idarede tutulan kayıtlar Timar Ruznamçe Defterleri'nde yer almaktadır. Söz konusu bu defterlerde, vilayetlere ait timar sisteminin işleyişi ve tezkereler, mülk ve timarı tasarruf eden kişilerin adları, timar hasılları, biyografileri, kariyerleri, kökenleri, askeri faaliyetleri, idari anlamda üst mercilerle kişisel ilişkileri, fiziksel özellikleri, timar gelirlerinin farklı bir kişiye aktarılmasının şartları ve sebepleri ile timara ne kadar süre sahip olunacağına dair bilgiler bulunmaktadır. $\mathrm{Bu}$ bilgilere ek olarak, dirlik sahiplerinin gelirlerini hangi tür kaynaklardan elde ettiği ile beraber bu gelirlerin sağlandığı kırsal yerleşmeler hakkında da bilgiler verilmektedir. ${ }^{52}$ Nitekim burada yapılan inceleme neticesinde timar sahibinin iddiasında haklı olduğu belirlenmiş ve yerel idarecilerin bu minval üzere işlem yapmaları istenmiştir.

Timar sahipleri yalnızca diğer timar sahipleriyle değil aynı zamanda bir nevi geçimliklerini elde ettikleri reaya ile de sorunlar yaşamışlardır. Bu tarz bir durumu gösteren kayıtta Ömer isimli timar sahibinin kaydı ilgi çekicidir. Haho nahiyesinde yer alan timar köylerinden Haho (Bağbaş1) köyüne ait miktarı belirli ambarlanmış ürünlerinin aynı köyden kimliği belirli kişiler tarafından kanuna aykırı olarak gasp edilmiştir. Ayrıca adı geçen sipahi söz konusu kişilerden kanuni

\footnotetext{
${ }^{49}$ BOA. A.DVNS.AHK.ER.d. 3: 241/2. BOA. A. DVNSAHK.ER.d.003: 211/2.

${ }^{50}$ Halil İnalc1k, "Timar", TDVIA, C. 41, İstanbul 2012, s. 169.

${ }^{51}$ BOA. A.DVNS.AHK.ER.d. 3: 250/2. Benzer kayıt için bkz. BOA. A.DVNS.AHK.ER.d. 1: 182/1.

${ }^{52}$ Emine Erdoğan Özünlü, “Osmanlı İskan Tarihine Dair Önemli Bir Kaynak: Timar-Ruznamçe Defterleri” Hacettepe Üniversitesi Edebiyat Fakültesi Dergisi, C. 33, S. 1, 2016, s. 141.
}

\author{
History Studies \\ www.historystudies.net
}


haklarını talep ettiğinde de vermeye yanaşmamışlardır. Dolaysıyla timar sahibi hakkının kendisine iade edilmesini talep etmiş ve merkezi idare de bu doğrultudan mahallinde sorunun hal edilmesine yönelik hüküm vermiştir. ${ }^{53}$

Zeamet, timar sistemi içerisinde genel olarak askeri hizmette olan kişilere tevdi edilen 20 bin ile 100 bin arasındaki dirliklerdir. $\mathrm{Bu}$ dirlikleri elinde bulunduranlar da zaim olarak isimlendirilmektedir. ${ }^{54}$ Tortum kazasında timar sahipleri gibi merkeze şikâyetleri ulaşan bir diğer grup da zaimlerdir. 15-24 Aralık 1755 tarihinde Erzurum valisine ve Tortum kadisina yazılan hükümde, Musa oğlu Seyyid Ahmed Tortum kazasına bağlı Haho nahiyesinde Hartha (Cevizli) köyü ve gayrisinde 51250 akçelik zeamete $1755 / 56$ senesinin 19 . günü verilen beratla sahip olmuş ve Defter-i Hakani'ye uygun olarak bu zeameti kullanmaktadır. Seyyid Ahmed berat-1 şerifle sahip olduğu zeametin ürünleri ve vergilerini de kanuna uygun olarak aldığını belirttikten sonra zeametine dışarıdan müdahale ve zulmedildiğini bildirerek buna son verilmesini talep etmiştir. Merkezi idare durumu inceleyerek deftere uygun olarak hareket edilmesi hükmünü vermiştir. ${ }^{55}$ Her ne kadar kayıtta zeamet sahibi müdahale edenleri belirtmemiş olsa da var olan tehdidi açık bir şekilde dile getirmiştir. Şikâyeti yapan kişinin haklılığını dile getirmek adına delili veyahut da dayanağ 1 "Defter" ve "Kanun" dur. Devletin uygulanmasını istediği sistemin kaynağ 1 ve fiiliyat1 düzenleyen hükümler benzer şekilde ferd ferd toplumunda talep ettiği arzuladığı bir yapıdır. Dolayısıyla şikayetlerde dile getirilen ve öne çıkarılan asıl fikir devletten kendi varoluşunu korumasidir.

Devletin bir nevi hakem rolünü üstlendiği timar sistemi içerisinde sistemin asıl aktörleri dirlik sahipleri ve bu dirlikler üzerinde ekip biçen halktır. Devlet her iki tarafında bu kurgu içerisinde sağlıklı bir ilişki kurabilmesi için hukuki bir çerçeve ile sınırlamalar getirmiştir. Bu hukuki sınırı aşmak taraflardan birinin şikâyet hakkının doğmasına ihlali gerçekleştirenin ise devlet eliyle meşru çerçeveye yeniden dahil edilmesine yol açmaktadır. Örneğin 21-29 Kasım 1750 tarihli kayıta göre zaim İbrahim Erzurum, Pasinler, Tortum sancaklarında ve diğer nahiyelerde İs Kalesi köyü ve diğer yerlerde 50.819 akçe zeamet sahibidir. Zeameti sınırları içerisinde Tortum sancağ 1 Haho nahiyesinde 18 bin akçe tutarlı Tiv (Çağlayan) köyü de bulunmaktadır. Ancak zaim İbrahim müstakil beratı olmasına dayanarak, mahsul ve vergi talep ettiğinde köy ahalisi hep birlikte bu duruma karşı çıkarak "köyümüzü, mahsullerimizi ve vergilerimizi sana vermeyiz ancak senede bir miktar nakdi bedel öderiz" demişlerdir. Mevcut durum incelenerek Defter-i Hakani' deki kayıt doğrultusunda ahaliden vergilerin alınması hükmü yazılmıştır. ${ }^{56}$ Sistem içerisinde vergi vermekle yükümlü olan halkın vergiden kaçınma olarak ifade edilebilecek eylemleri merkezde tutulan kayıtlar esas alınarak devletin hukuki reflekslerini ortaya çıkarmıştır. Kayıttan anlaşıldığı üzere devletin varlığının temsilcisi konumundaki ehl-i örf hukuk çerçevesinde korunmuş ve sistemin dışına çıkan tavırlar içerisindeki halk hukuki zemine çekilmiştir.

28 Şubat-9 Mart 1750 tarihli benzer bir başka kayıtta şikayetçi Tortum sancağ1 Haho nahiyesine bağlı Öşk-i Sor köyü zeamet sahiplerinden İbrahim'dir. Topraklarını koruyan ve ziraatle uğraşan köylülerin elde ettikleri kazanç üzerinden kanun ve defter doğrultusunda ödemeleri gereken öşürleriyle bağ ve bahçelerinden elde ettikleri üzüm, meyve ve ayrica faydalandıkları meyveler için üzerlerine düşen öşürlerini talep ettiğinde köylüler buna itiraz ederek "biz bunun için öşür vermeyiz ancak maktuen şu kadar akçe veririz" demişlerdir. Ancak yapılan değerlendirme sonucu köylüler iddialarında haksız bulunarak ekip biçtikleri tarlalardan aldıkları ürünler ve bağ-bahçeden elde ettikleri meyveler için öşür vermeleri gerektiğine hükmedilmiştir. ${ }^{57}$ Hüküm içerisinde dikkat çekici husus zeamet toprağı üzerinde ziraatla

\footnotetext{
${ }^{53}$ BOA. A.DVNS.AHK.ER.d. 6: 53/3. Benzer bir kayıt için bkz. BOA. A.DVNS.AHK.ER.d.6: 53/2.

${ }^{54}$ Erhan Afyoncu, "Zeamet", TDVIA, C. 44, İstanbul 2013, s. 162.

${ }^{55}$ BOA. A.DVNS.AHK.ER.d. 3: 274/4. Benzer kayıt için bkz. BOA. A.DVNS.AHK.ER.d. 1: 168/2.

${ }^{56}$ BOA. A.DVNS.AHK.ER.d. 3: 47/1.

${ }^{57}$ BOA. A.DVNS.AHK.ER.d. 3: 11/3.
} 
uğraşanların yalnızca tarlarından ürettikleri vergilendirilmemekte buna ek olarak dirlik toprağ 1 üzerinde yetișen her türlü mamulden zeamet sahibinin hakkı olmasıdır. Köylünün talebi sabit ve nakdi bir bedel vermektir. Bu talep bir nevi ne ödeyeceğini bilmek ve ona göre geçimlik planlamasını yapmak arzusudur. Ancak benzer bir durum vergiyi talep eden zaim için de geçerlidir. Dolayısıyla zeamet sahibi devletin sağladığı hak çerçevesinde var olan tüm gelir kaynaklarını eksiksiz talep etmektedir.

22-31 Mayıs 1746 tarihinde Erzurum valisi ve Tortum kadılarına hitaben yazılan hükümde, bölgede zeamet sahiplerinden Kağıt Emini İbrahim adlı kişi Erzurum, Pasin ve Tortum sancaklarında ve diğer nahiyelerde, İs Kalesi köyü ve diğer köylerde toplam 50.819 akçe değerinde zeamete resmi berat ile sahip olduğunu ayrıca Tortum kazasına bağlı Haho nahiyesi köylerinden biri olan 10 bin akçe bedelli Tiv köyünde de tarlalardan elde edilen ürünlerden, bağlardan, ormanlardan, bahçe ve bostanlardan elde edilen ürünlerden hakk1 olan öşür vergisini talep ettiğinde adı geçen yerleri ekip biçen köy halkının "bizler öşür vergisi vermeyiz daha önce sözlü olarak anlaştığımız üzere senede bir miktar akçe bedel veririz" diyerek itiraz etmişlerdir. $\mathrm{Bu}$ iddia doğrultusunda da hâlihazırda öşürlerini ödememekte direnmektedirler. Zeamet sahibi konuyu yargıya taşımış ve haklılığı noktasında elinde fetva-yı şerif de bulunmaktadır. Defter-i Hakani'de de iddia sahibinin ifade ettiği üzere köyün öşrünün kendisine ait olduğu belirlenmiş olduğundan köy halkının kanuna aykırı hareketten menedilmesine hükmedilmiştir. ${ }^{58}$

Tortum gibi taşrada gelir kaynaklarının sınırlı olduğu bir alanda vergi toplanabilen arazi ve insan kaynaklarının arzu edilenden fazla taliplisi ortaya çıkmaktadır. Bu durumda haliyle bir paylaşım mücadelesi kaçınılmaz hale gelmektedir. Bu tarz bir mücadeleyi göstermesi açısından 4-12 Mart 1747 tarihli Tortum kadısına yazılan hükümde ilginç veriler yer almaktadır. Ebubekir Tortum Sancağı'nda Haho nâhiyesi'nde Otha (Kirazlı) köyü ve mezrası Gürpınar'da 20.500 akçe değerinde zeametin sahibidir ve buradan alınan cürm-i cinayet ve resm-i arusane, kul ve câriye müjde-gâneleri, ve diğer bâd-1 hevâ vergilerine dışardan müdahale edilmemesi gerekmektedir. Ancak Ebubekirin tasarrufunda bulunan zeamet bölgesine dişarıdan yeniçeri, sâdât ve ehl-i örf grubundan bazı idareciler yürürlükteki kanunların aksine davranarak rüsûm-1 serbestiye ve diğer bâd-1 heva vergilerini Ebubekir'in elinden almaktadır. Ebubekir'in iddiası Defterhane'de bulunan Ruznamçe-i Hümayun ve İcmal Defteri'nden kontrol edildiğinde kayıtların zeamet sahibinin şikayetinde yer verdiği ölçülerde olduğu tespit edilmiş ve bu şekilde sorunun çözülmesine dair hüküm yazılmıştır. ${ }^{59}$ Örfi bir vergi türü olarak bad-ı heva vergileri; cürm-i cinayet, gerdek resmi, çiftlik tapusu, ev tapusu, tütün veya duhan resmi, abd-i abık veya kenîzek muştuluğu (yakalanan köle bedeli), Yâve(kayıp hayvan), beytül mâl, mâl-i gâib ve mâl-i mefkûd, deştibâni (bekçilik) isimleri altında timar sahipleri tarafından reayadan alınırd $1 .{ }^{60}$ Rüsum-1 serbestiyyet de yine toprağ 1 tasarruf edenler tarafından alınan vergileri ifade ederdi. Bu vergiler cürm-i cinayet, arus, kul ve cariye müjdeganesi gibi bad-1 heva türünden vergilerdi. ${ }^{61}$ Adı geçen bu vergiler timar sahibinin tasarruf ettiği iktisadi alandaki gelir kalemleri idi. Ürün üzerinden alınan vergilerde oransal oynamalar ve sapmalar olsa da söz konusu vergilerde sabit bir kazanç söz konusudur. Dolayısıyla bölgede yer alan ehl-i örf grubunun bu kazanç denklemi içerisine dahil olma isteği çatışmalara yol açıyordu. Bu çatışma hususunda çözüm mercii olan Divan-1 Hümayun adaleti tesis etmek adına hareket ederek hem Timar Ruznamçe Defteri hem de İcmal Tahrir Defteri'ndeki kayıtlardan yola çıkarak hükmünü vermiş̧ir. Yalnızca idari teşkilata göre vilayet, sancak, kaza, nahiye, köy ve mezraa isimlerini ve hasıl miktarlarını, timar sahibinin kimlik ve niteliğini müșterekini, timarın parçalanması, hisseler vb. içeren defterlere İcmal Tahrir Defterleri adı verilirdi. ${ }^{62} \dot{I} \mathrm{cmal}$ defterlerde

\footnotetext{
${ }^{58}$ BOA. A.DVNS.AHK.ER.d. 1: 148/5.

${ }^{59}$ BOA. A. DVNS.AHK.ER.d. 1: 184/4.

${ }^{60}$ Halil Sahillioğlu, "Bâd-ı Hevâ", TDVIA, C. 4, İstanbul 1991, s. 417.

${ }^{61}$ Halil Sahillioğlu, "Resim", TDVIA İslam Ansiklopedisi, C. 34, İstanbul 2007, s. 583.

62 Feridun M. Emecen, "Mufassaldan İcmale", Osmanl Araştırmalarl, C. XVI, İstanbul 1996, s. 40.
}

\author{
History Studies \\ www.historystudies.net
}


yer alan timar sahibinin isim ve niteliği verisi Divan-1 Hümayun'a gelen şikayetlerin çözümünde önemli rol oynamıştır. Genel itibariyle. Tortum kazasında timar ve zeamet konusunda yaşanan hukuki anlaşmazlıkların çözümünde öne çıkarılan kaynaklar Mufassal ve İcmal Tahrir Defterleri ve bunlara dayalı olarak hazırlanan Timar Ruznamçe Defterleri olmuştur.

\subsection{Veraset Anlaşmazlığı}

Miras paylaşımı insanlık tarihi boyunca akrabalar arasında problemler yaşanmasına yol açmıştır. Adalet sağlanmadığı takdirde önce aileler arasında geçimsizliğe neden olan miras daha sonra genel bir huzursuzluğa yol açabilmektedir. İslam miras hukukuna göre ölen bir kişinin arkasından öncelikle birinci derece akrabaları olmak üzere paylaşımın nasıl yapılacağı belirlenmiştir. Ancak bugün de olduğu gibi kanun hiçe sayılarak hak gaspının yaşandığı örnekler mevcuttur. Örneğin 28 Ekim-6 Kasım 1754 tarihli Tortum kadısına gönderilen hükme göre, Os/Oset (Erikli) köyü sakinlerinden Ahmed ve Mustafa adlı kardeşler annelerinin ölümü üzerine ondan kalan mal, eşya ve terekesinin tek mirasçısı iken yine aynı köyde, ölen kadının akrabalarından İsmail Beşe ortaya çıkarak annelerinden kalan mal, eşya ve terekesinde hak iddia ederek zabt etmiştir. Adı geçen iki kardeş haklarını talep ettiklerinde ise davalı İsmail gasp ettiklerini vermediği gibi zorbalık etmekten de çekinmemiştir. Mevcut durum incelendikten sonra bahsi geçen İsmail'in zulüm ve zorbalığına son verilerek kanuna uygun bir şekilde davanın sonlandırılması konusunda hüküm yazılmıştır. ${ }^{63}$

\subsection{Gasp}

Hanefi fıkhına göre gasp, başkasına ait değerli ve dokunulmaz bir malı sahibinin izni olmadan elinde ise sahipliğini yok ederek almak, elinde değilse de sahibinin mala ulaşmasına engel olmak olarak tanımlanmaktadır. ${ }^{64}$ Gasp açık bir adaletsizlik ve zulümdür. Tüm suçlar gibi toplumsal düzenin yara almasına ve adalet duygusunun zayıflamasına yol açmaktadır. Gasp konusunda Tortum kazasından iki şikâyet üzerinde durmak açıklayıcı olacaktır. 6-14 Haziran 1798 tarihli birinci şikayette, Tortum kazası Oluk? köyünden Seyyid Mustafa ve Seyyid Hüseyin babaları Seyyid Ali'den kendilerine intikal eden mülk, bahçe, mal ve eşyayı yine ikamet ettikleri köyde yaşayan Lovoğlu Hasan Beşe, Kayığlu Hasan Beşe ve Fatma adındaki bir kadının iş birliği yaparak gasp ettiklerini bildirmiştir. Hükmün sonunda Tortum kadısından problemin kanunlar çerçevesinde çözümlenmesi istenmiştir. ${ }^{65}$ 12-21 Aralık 1776 tarihli ikinci kayıtta ise Yakup adlı kişi vefat eden Ömer'den kendisine intikal eden mal eşya ve paranın icra ve ihkak-1 hak yoluyla alınmasını istemiştir. Merkezi idare de durumun incelenerek kanun çerçevesinde değerlendirilmesi için hüküm vermiştir. ${ }^{66} \mathrm{Her}$ iki olayda da dışarıdan haksız bir müdahale söz konusudur. Birincisinde miras ikincisinde ise muhtemel bir ticaretle intikal eden mal, kişi veya grup tarafından gasp edilmiştir. Bu tarz bir şikâyetin çözümü için başvurulacak resmi bir kaynak mevzubahis değildir. Ancak şikâyetin ciddiye alınarak durumun hukuk çerçevesinde çözümlenmesi, devletin taşradaki adalet eli olan kadıya tembihatta bulunulması değerli bir hukuki usul olarak dikkate değerdir.

\subsection{Yaylak-Kıșlak, Koru ve Su Kullanımına İlișkin Anlaşmazlıklar}

Osmanlı hukuk sistemi şeriat ve örf olmak üzere iki ana kaynaktan teşekkül etmiştir. İslami hükümler pek çok alanda belirleyici ve çözümleyici rol üstlenmiştir. Arazi kanunnamelerinde de bunu görmek mümkündür. Kamunun kullanımına tahsis edilen alanlara ilişkin kanuni düzenlemeler "himâ" kavramı kapsamında değerlendirilmiştir. Himâ kavramının İslam

\footnotetext{
${ }^{63}$ BOA. A.DVNS.AHK.ER.d. 3: 215/2.

${ }^{64}$ Kamil Yelek, Gasp ve İtlaf Bağlamında Hanefi Sorumluluk Hukuku, İstanbul Üniversitesi Sosyal Bilimler Enstitüsü Temel İslam Bilimleri Ana Bilim Dalı İslam Hukuku Bilim Dalı, Yayınlanmamış Doktora Tezi, İstanbul 2019, s. 127.

${ }^{65}$ BOA. A.DVNS.AHK.ER.d. 9: 94/2.

${ }^{66}$ BOA. A.DVNS.AHK.ER.d. 6: 53/4.
} 
devletlerinin çeşitli dönemlerinde farklı anlam ve uygulamalarına rastlansa da Osmanlı arazi hukukunda himâ kavramı devlet hazinesine ait olan arazinin herhangi bir kimseye mülk olarak verilmeyen, birinci kısmın koru, mera, yaylak ve kışlak gibi belli köy ve kasabalar ahalisinin menfaatine uygun şekilde terk ve tahsis kılınan mahaller olduğunu ikinci kısmın ise ana yol, pazar yeri, meydanlar, sokaklar gibi kamunun yararlanma ve kullanımı için terk edilen mahallerden ibaret olduğu ifade edilebilir. ${ }^{67}$ Koruluk alanlar bugün de her bir kırsal birim için farklı alanlarda tahsis edilmiştir. Bu alanlar köy tüzel kişiliğine ait olup farklı kişi veya grubun buralara dışarıdan gelerek yerleşmesi veyahut da izinsiz tasarrufta bulunması yasaktır. Bugünün kuralları geçmiş tecrübelerin birikimi sonucu oluşmaktadır. Bu doğrultuda Tortum kırsalında yaşanan birtakım sorunlar konunun anlaşılması açısından ehemmiyet taşımaktadır.

28 Haziran-6 Temmuz 1758 tarihinde Erzurum valisi vezire ve Tortum kadısına gönderilen hükümde, Tortum kazası Ekik (Vişneli) köyü ahalisi köyleri yakınında tapulu ve temessüklü kadim defterde kayıtlı eskiden beri mahsus ve müstakil tasarruflarında bulunan korularına kimsenin müdahale hakkı olmamasına rağmen adı geçen kazada yer alan Çöre, Harteniz vs. köy ahalileri haksız bir şekilde koruya müdahale etmişlerdir. Daha önce bu anlaşmazlıkları üzerine görülen davada adı geçenlerin koruluk alanın kullanımında hakları olmadığı ve kesinlikle buraya müdahale haklarının bulunmadığına dair Ekik köyü ahalisine hüccet verilmiştir. Ancak bu kişiler bunu da tanımayarak zulüm ve müdahaleden geri durmamışlardır. $\mathrm{Bu}$ sebeple söz konusu köylülerin kanuna aykırı fiillerinin önlenmesi ve meselenin kanuni çerçevede çözümlenmesi maksadıyla hüküm yazılmıştır. ${ }^{68}$ Koruluk alanlar tahsis edildiği köyler için hayvanların otlatılması, yakacak vb. imkânları sebebiyle vazgeçilmez geçimlik ve yaşamsal alanlardır. Örnekte görüldügü üzere koruluk alana birçok köyün müdahalesinin olması top yekûn bir köy halkının şikayetine sebep olmuştur. Ortak bir kullanım alanının tecavüze uğraması çözüm talebinin arkasında bir birleşme ve ortak bir hareketi doğurmuştur.

Koruluk alanların yanı sıra yaylak ve kışlak arazilerin kullanımında çeşitli aksaklıkların yaşandığı merkezi idareye yansıtılmıştır. 7-15 Temmuz 1749 tarihli ahkam kaydında Erzurum valisi ve Tortum kadısına yazılan hükümde, Mehmed isimli kişi ismi belirtilmeyen bir köyde tapulu ve senetli arazisi içerisinde yer alan yaylaya zamanında koyun ve davarlarıyla çıkarak yaylayanlar, otundan ve suyundan fayda sağlayıp gücü nispetinde de vergisini vermektedirler. Ancak Tortum'da ikamet eden Merdus? cemaatinden Abdülhay ve Tahir adlı kişiler "Biz bu yaylağı 1747/48 senesinde senin babandan satın aldık" diyerek kanuna aykırı ve senetsiz olarak Mehmet'in elinden almışlardır. Durumun incelenerek kanunlar çerçevesinde sorunun halledilmesine yönelik hüküm yazılmıştır. ${ }^{69}$ Kişisel bir hak ihlaline örnek teşkil eden bu durum mahallinde çözümlenememiştir. Yereldeki acziyetin sebebi bahsedilen kişilerin arkasında muhtemel bir aşiret desteği olabilir. Ancak fert olarak hak aramaktan vazgeçilmemiş olmasi adalete olan güvenden ileri gelmektedir. Bu hususta bir başka şikâyette şikayetçiler vakıf mütevellileridir. Bekçi Ahmed vakfının mütevellileri olan Ahmed, Mustafa ve ( ) adındaki köy sakinleri Divan-1 Hümayun'a bizzat gelerek şikayette bulunmuşlardır. İddialarına göre, Tortum kazasına bağlı Eğriçayır köyü toprağında bulunan yaylak ve kışlağın vergileri vakıf defterine hasıl yazılmaktadır. Bahsedilen kışlak ve yaylağa, koyun ve sair davarlarıyla konar ve göçer taifesinden Merdus? aşiretinden Vadinoğlu Mustafa adındaki kişi çıkıp, yaylayıp, kışlayıp otundan ve suyundan yararlanmıştır. Kendisinden yaylak ve kışlak resimleri talep edildiğinde kanun ve deftere aykırı olarak vergilerini vermeyerek vakfı zarara uğratmıştır. Durum incelenmiş ve kanuna aykırı uygulamaların önlenmesi ve kurallara uygun işlem yapılması için hüküm yazılmıştır. ${ }^{70}$ Bir önceki kayıttan farklı olarak yaylak ve kışlağın haksız kullanımı bir vakfı zarara

\footnotetext{
${ }^{67}$ Hacı Mehmet Günay, "Himâ", TDVIA, C. 18, İstanbul 1999, s. 52-53.

${ }^{68}$ BOA. A.DVNS.AHK.ER.d. 4: 44/1.

${ }^{69}$ BOA. A.DVNS.AHK.ER.d. 1: 285/4.

${ }^{70}$ BOA. A.DVNS.AHK.ER.d. 4: 202/3.
}

\author{
History Studies \\ www.historystudies.net
}


uğratmıştır. Vakıflara ayrılan arazilerden elde edilen gelirler sosyal amaçlı uygulamaların ana gelir kaynaklarıdır. Bu kaynaklardaki kesinti vakıfların fonksiyonelliğini kısıtlayacağı gibi toplumun yeterli hizmet alamamasına da sebep olacaktır. Dolayısıyla bu başvuru ferdi bir şikâyetten öte kamunun hakkını savunma olarak anlamlıdır.

Tortum kırsalında sadece arazi üzerinden anlaşmazlık yaşanmamıştır. Doğal bir kaynak olarak su ve suyun kullanım hakkı da köyler arası çekişmenin merkezindedir. 20 Ağustos 1743 tarihli Erzurum valisi ve Tortum kadılarına gönderilen hükümde, Tortum kazasına bağlı Norşin (Karlı Köyü) köyü halkının şikâyetine göre; eskiden beri sahip oldukları suya yine bu bölgede yer alan Keğik (Kapıkaya köyü) köyü halkı hiçbir hakları olmadığı halde hukuksuz bir müdahalede bulunmaktadır. Keğik köylüleri müdahale etmekle kalmayıp bahse konu suyu keserek kendi köylerine akıtmışlardır. Bu noktada Norşin köylüleri zulme uğradıklarının resmi olarak da ellerindeki fetva şerifle belgelendiğini belirterek bu belge doğrultusunda Keğik halkının hukuksuz müdahalelerinden menedilmesi istemiştir. ${ }^{71}$ Su kaynakları yerleşimin temel unsurudur. Tarıma dayalı ekonomik sistemlerin ön planda olduğu bir sistem içerisinde ise suyun değeri vazgeçilmez orandadır. Bunun tabii neticesi ya adil bir paylaşım veyahut da önlenemez çatışmaların ortaya çıkmasıdır. Bireylerin çıkar merkezli mikro yaklaşımları paylaşımın adalet temelli olmasına engel olmaktadır. Nitekim bahsi geçen olayda fertlerin ötesinde iki köy halkı karşı karşıya gelmiştir. Genelin menfaatinin hiçe sayıldığı böylesi bir durumun çözümü ise devletin hakemliği olmuştur.

\title{
3.5.Vergi Anlaşmazlıkları
}

Devlet, tüm hizmetlerini yürütmek, harcamaları yapmak, halka karşı görevlerini yerine getirmek adına çeşitli alanlarda ve isimler altında halktan vergi almıştır. Ancak devletin devamlılığını sağlamak adına topladığı vergiler dışında bir şekilde devletle bağı olan görevlilerin keyfi uygulamaları verginin meşruiyet sorununu doğurmaktadır. Bir örnek üzerinden durum açıklanacak olursa; 26 Temmuz 1759-4 Ağustos 1759 tarihli kayıtta Tortum kadısına yazılan hükümde, Tortum kazası Liskav nahiyesinin Hinzorik (Taşoluk/Yamankaya) köyü ahalisi bir arzuhal ile Divan-1 Hümayun'a başvurarak, köyleri üzerinde 240 akçe bedelle avarız bulunduğu, avarızlarını ve diğer yükümlülüklerini kanun çerçevesinde ödedikleri dolayısıyla üzerlerine herhangi bir ekstra külfet gerekmez iken, köylerinin Kars, Ahıska ve Gürcistan taraflarına giden yol üzerinde olması nedeniyle tekalif-i şakka veya farklı adlar altında istenen vergiler nedeniyle rencide, perakende ve perişan olduklarını bildirerek söz konusu olumsuzlukların giderilmesini talep etmişlerdir. Şikâyet üzerine Ruznamçe Defterlerine başvurulmuştur. Buradaki kayıtlara göre, Liskav nahiyesi Hınzorik (Taşoluk/Yamankaya) köyü 13.000 akçe yazarı olduğu 6500 akçesi Osman'ın zeameti, Haho nahiyesi Hars (Ulubağ) köyü ve diğer yerlerden 21.206 akçe bedel zeamete mutasarrıf olan diğer Osman uhdesinde olduğu belirlenmiştir. Ayrıca Defter-i Hakani kayıtlarına göre adı geçen köyün belirlenmiş 240 akçelik avarız vergisi yükümlülüguü kayıtlıdır. Divan-1 Hümayun kalemine sorulduğunda Hınzorik (Taşoluk/Yamankaya) karyesi ahalisinin tekalife yeterlilikleri olmadığı Defter-i Hakani kayıtlarına göre avarızlarını ödemeleri ve yine kanuni vergilerini emir ve defter doğrultusunda ödemeleri gerektiği belirtilmiştir. ${ }^{72}$

Avârız-1 divaniye, divan kararı ya da padişah emriyle toplanan vergilerdir. İlk dönemlerde savaş zamanlarındaki masrafları karşılamak için toplanırken, sonraları hazinenin sıkıntısını gidermek amacıyla sürekli başvurulan bir vergiye dönüşmüştür. Söz konusu vergiler yerleşimlere topluca konup, hane başına oranlanarak ve taksitle ödenirdi. Önceleri aynî iken 1718'den itibaren nakdî olarak tahsil edilmeye başlanmıştır. Başlıca avârız vergileri; imdâdiye-i seferiye, imdâdiyei hadâriye, iâne-i cihâdiye, avârız akçesi (avârız hanesi başına alınan ve zamanla paranın değerinin düşmesine paralel olarak miktarı artırılan maktu ve nakdi bir vergi), nüzûl, sürsat ve iştira

\footnotetext{
${ }^{71}$ BOA. A.DVNS.AHK.ER.d. 1: 49/1.

${ }^{72}$ BOA. A.DVNS.AHK.ER.d. 4: 103/4.
}

\author{
History Studies \\ www.historystudies.net
}


bedelleri isimleriyle alınan vergilerdir. ${ }^{73}$ Tekalif-i şakka ise şer'i kabulü olmayan ve genel itibariyle haksız kabul edilen yükümlülüklerdir. Bu tür vergiler her ne kadar ferman ve adaletnamelerle yasaklanmısssa da memurlar tarafindan izinsiz olarak alınmaya devam edilmiştir. ${ }^{74}$ Vergi usulsüzlüğü yöneticilerin halktan ödemesi gereken miktardan daha fazlasını talep etme, kanuna aykırı çeşitli isimler altında vergi talep etme, mükerrer vergi talebi, vergi toplama hakkı olmayanların halktan vergi talebi, vergi yükümlülüğü olmayanlardan vergi talebi gibi çeşitli şekillerde gerçekleşmektedir. ${ }^{75}$ Ahkam kaydında belirtildiği üzere avarız vergilerini sorumlulukları olduğu için ödeyen halkın üzerine kanunsuz vergiler konulmuştur. Köylüler aslında başlarına gelen olumsuzluğun sebebini açık bir biçimde ortaya koymaktadır. Köylerinin yol güzergâhı üzerinde yer alması güvenli bir ortamda avantaj teşkil ederken kanunsuzluğun kol gezdiği bir ortamda dezavantaja dönüşmektedir. Köylerin kolay ulaşılabilir konumda olması ehli örf grubundan pek çok görevlinin uğrak alanı olmasına ve usulsüz vergi taleplerine neden olmaktadır. Köylünün ödeyeceğinden fazla vergi talebi zamanla vergiden kaçışa sebep olacaktır. Nitekim köylünün "rencide, perakende ve perişan" olduklarını belirtmesi bulundukları alandan pek çok kişinin farklı kır veya kent bölgelerine göç ettiğini göstermektedir. Anadolu'nun pek çok bölgesinde vergi baskısının da içinde bulunduğu çeşitli sebeplere bağlı olarak yaşanan göçler ${ }^{76}$ iskân alanlarının (köy/mezra) terk edilmesine ve köylerin kaybolmasına neden olmuştur. ${ }^{77}$

\title{
3.6.Eşkıyalık
}

Eşkıyalık, devlet içerisinde yaşamasına rağmen devlet otoritesine karşı hareket eden ve iktidardan çok halka zarar veren kişi veya grupların kanunsuz fiilleri olarak tanımlanmıştır. ${ }^{78}$ Eşkıyalık müesses nizama karşı bir başkaldırı niteliği taşımaktadır. Bu sebeple eşkıyalık faaliyetleri adaleti ve güvenliği hedef alır. Devletin bu gruplara karşı ilk tepkisi çoğunlukla toplumu terörize eden kişi veya grupları ortadan kaldırarak sorunun halline yöneliktir. Eşkıyalar işin tabiatı itibariyle saklanması kolay ormanlık ve dağlık alanları ikamet seçmişlerdir. Hedefleri ise genellikle zengin köyler ve ticaret yapılan güzergâhlar, yollar olmuştur.

Tortum kazasına ilişkin incelenen dönem Ahkâm Defteri kayıtlarında eşkıyalıkla ilgili şikayetlerde yer almaktır. Bu kayıtlardan ilki Hemşinli Molla Hüseyin'in şikâyetidir. Hüseyin, babası Ahmed oğlu Ali ve arkadaşları İbrahim ile Yahya 1759/60 senesinde ticaret maksadıyla Erzurum tarafına giderken Tortum'a bağlı Sürbahan (Dikmen) köyünden Kara Osmanoğlu Mehmed, Kılçık Hasanoğlu Ömer ve oğlu ile Haho köyünden birkaç kişi birleşerek Haho köyü

\footnotetext{
${ }^{73}$ Ahmet Akgündüz, İslam ve Osmanlı Hukuku Külliyatı: Kamu Hukuku, Osmanlı Araştırmaları Vakfi Yay., İstanbul 2011, s. 710-711.

${ }^{74}$ Ahmet Tabakoğlu, “Tekalif”, TDVIA, C. 40, İstanbul 2011, s. 336-337.

${ }^{75}$ Alpaslan Demir, Osmanlı Devleti'nde Vergilerin Göçlere Etkisi ve Kayıp Köyler Meselesi ”, Dede Korkut'un İzinde 30 Yll Prof.Dr. Üçler Bulduk'a Armağan Türk Tarihine Dair Yazılar, Gece Kitaplığı, Ankara 2017, s. 449-461.

76 Bkz. Alpaslan Demir, "Erzincanlı Göçmenler ve İskân Tarihi Açısından Önemi”, IV. Uluslararası Canik Sempozyumu Geçmişten Günümüze Şehir ve Çocuk, 15-17 Mayıs 2015, C. I, Samsun 2016, s. 403-408, Alpaslan Demir, "Karahisar-1 Şarki'li Göçmenler ve İskân Tarihi Açısından Önemi”, INOCTE 2016, International New Tendencies Congress in Ottoman Researches, October 7-9, Sarajevo 2016, s. 57-68, Alpaslan Demir, "XV. Yüzyllın İkinci Yarısında Tokat Şehrinde Göçmenler”, Tokat Sempozyumu 01-03 Kasım 2012, C. I, Tokat 2012, s.83-95.

${ }^{77}$ Kayıp köyler konusunda yapılan çalışmalar için bkz. Osman Gümüş̧̧ü, Alpaslan Demir, Emine Erdoğan Özünlü, Türkiye'nin Kayıp Köyleri, Yeditepe Yay., İstanbul 2020, Osman Gümüşçü, "Gözlemcilerin kaleminden Osmanlı Dönemi Yerleşmelerin Terk Edilmesi ve Kaybolması", Kitap Dostu Prof. Dr. Ali Birinci Armağanı, Polis Akademisi Yay., Ankara 2017, s. 479-502, Emine Erdoğan Özünlü, "Osmanlı Devleti'nde Nüfus Artış1, Göçler ve Kaybolan Yerleşmeler (XVI-XVII. Yüzyıl)”, Avrupa Tarihinde Türk Eli Doç. Dr. Gümeç Karamuk Armağanı, Hacettepe Üniversitesi Yay., Ankara 2017, s. 127-136, Alpaslan Demir, "Osmanlı Devleti'nde Yörükler ve Yerleşiklerin Kavgası: Kayıp Köyler Meselesi” Gazi Akademik Bakış, C. 11, S. 21, 2017, s. 15-31, İlker Yiğit, "İskandaki Kararsızlık: Doğal Afetler ve Kaybolan Yerleşmeler (XVI-XX. Yüzyıl Manisa-Konya Çevresi Örneği)", Hacettepe Üniversitesi Türkiyat Araştırmaları Dergisi, S. 26, Ankara 2017, s. 329-364.

78 Hakan Yaşar, II. Meşrutiyet'in Illanından Yunan İşgaline Batı Anadolu'da Eşkıyalık (1908-1919), Ankara Üniversitesi Türk İnkılap Tarihi Enstitüsü, Yayınlanmamış Doktora Tezi, Ankara 2015, s. 8.
}

\author{
History Studies \\ www.historystudies.net
}


yakınlarında yollarını kesip mallarını yağmalamışlardır. ${ }^{79}$ Hem ulaşım hem de ticari işleyiş açısından yolların güvenliği son derece önemlidir. $\mathrm{Bu}$ tarz eylemler bölgedeki güvenlik zafiyetinden kaynaklanmaktadır. Dolayısıyla bölge insanının beklentisi olaylara devletin derhal müdahalesi yönündedir. Nitekim merkezi idare mahallinde kanunun gereğinin yapılması için Erzurum valisi ile Tortum ve Hemşin kadılarına hüküm göndermiştir.

2-11 Şubat 1756 tarihli bir diğer ahkam kaydında, Zinavur (Kazandere) köyünden Osman'ın evi Dankar (Kırmalı) köyünden eşkıya zümresinden Bekiroğlu Osman ve oğulları Ali, Salih, İsmail ve enişteleri Ali tarafından basılarak 15 kese akçelik mal, eşya ve erzakını yağmalamışlardır. Hakkını talep eden Osman ve ismi geçen kişiler arasında görülen davada hakemlik için görevlendirilenlerin de eşkıyaların tarafını tutması adalet terazisinin tamamıyla şaşmasına sebep olmuştur. Neticede konu Divan-ı Hümayun'a taşınmıştır. Bölgedeki vezire hitaben yazılan hükümde adı geçen kişilerin zulmüne son verilerek gerekli cezalara çarptırılmaları emr olunmuştur. ${ }^{80}$ Kayıttan da anlaşılacağı üzere eşkıyalık sadece yol kesmekten ibaret değildir. Varlığı olan her kişi eşkıyaların hedefi halindedir. Haneye tecavüz ve gasp şeklinde gerçekleşen bu olayda taş çok uzaktan gelmemiştir.

\title{
Sonuç
}

Analitik bir yöntemle ele alınan sorun alanları ve taşraya yansımaları çalışmanın sınırlarını ve etki alanlarının berraklaşmasına katkı sağlamışır. Ancak katı kalıplar içerisinde farklı kulvarlara hasredilmiş analizler parçalar arasındaki korelâsyonun sağliklı değerlendirilememesine yol açabilir. $\mathrm{Bu}$ nedenle çalışmada belirtilen sorunsalları birbirinden kopuk olmaktan ziyade reel karşılıklarıyla birbirlerini destekleyen ve olumsuzluğu katmerleştiren unsurlar olarak da betimlemek mümkündür. Tek tek Osmanlı devlet düzeninde gedikler açılmasına yol açan değişkenlerin ötesinde devletin idari ve ekonomik açıdan yaşadığı hantallık ve rutinleşme hali asli sorun kaynağı olarak öne çıkmaktadır. Dünya tarihi yeniden yazılırken ve batı merkantalist ekonomi, sermaye birikimi, üretim kalıpları ve teknolojik atılımlarıyla siyasi, iktisadi ve askeri anlamda dünyayı domino ederken Osmanlı devletinin durağanlığı veya 1slahat teşebbüslerindeki başarısızlıkları işleyiş̧in her nüvesinde olumsuzlukları beraberinde getirmiştir.

Toprağa dayalı üretim ve tüketim modellerinin egemen olduğu çağların devletleri modern üretim ve tüketim kalıplarına adaptasyonları ölçüsünde başarılı oldular ve hayatiyetlerini sürdürdüler. Timar sistemi ile askeri, idari ve iktisadi anlamda taşrayı merkezi otoriteye bağlayan ve tüm çıktılarıyla bir devlet omurgasının tesis edildiği büyük bir zaman dilimi başarıyla geçirilebilmiştir. Ancak değişen ekonomik ve askeri dengeler timar sisteminin 16. yüzyıl sonları itibariyle Osmanlı Devleti'nin ihtiyaçlarına cevap veremez hale geldiğini göstermektedir. Sistem bir anda lağvedilmemiş ama etki ve kullanım alanı yıllar geçtikçe daraltılmıştır. 18. Yüzyıl Tortum bölgesinde timar sistemine dair işleyiş, paylaşım ve vergilendirme anlamında sorunların yaşandığı bir zaman dilimidir. Bu durum imparatorluğun genelinden farklı bir hal de değildir.

Divan-1 Hümayun'a başvurulabilmesi adalet sisteminin işleyişi açıdan bir bakıma olumludur. Ve genel itibariyle de bu şekilde değerlendirilmektedir. Ancak şikâyet konularının mevcut düzenin işleyişi açısından önem derecesi baz alındığında, bu tarz meselelerin yerelde çözümlenemiyor olması düşündürücüdür. Adalet mekanizmasına olan güven duygusunun azalmasından midır? yoksa adaletin yereldeki uygulayıcılarına olan itimadın sarsılmasından mıdır? bu sorunun cevap bulması taşra hukuk uygulamaları açısından belirleyici olacaktır. Şikâyet cümlelerinin arasında sitayişle bahsedilen hakem merciindeki kişilerinde güçlüden yana tavır almaları bu noktada bir cevap olabilir. Ayrıca bazı davalarda hüccet-i şeriyye alınmasına rağmen zulmün devam ettiği vurgusu adaletin sadece mahkeme kararlarıyla değil devlet gücünü temsil

${ }^{79}$ BOA. A.DVNS.AHK.ER.d. 4: 259/3.
${ }^{80}$ BOA. A.DVNS.AHK.ER.d. 3: 305/3.

\author{
History Studies \\ www.historystudies.net
}


eden kolluk kuvvetlerinin de acziyeti sebebiyle problemlerin devletin merkezine kadar ulaşmasına neden olmuştur.

Devletin olaylara yaklaşımı, bireye verdiği önem verilen adli hükümler ölçeğinde dünya görüşü tespit edilebilmektedir. Devletin ücra bir köşesindeki kişinin şikayetinin en üst mercii tarafından kaale alınıyor olması birey devlet ilişkisini kuvvetlendirici bir uygulamadır. Ancak bu tarz bir emniyetin tesisi zamanla hemen her şeyin merkeze taşınmasına ve yı̆̆ılmalara neden olmuştur. Nitekim başlangıçta Divan-1 Hümayun'dan çıkan kararların kaydedildiği Mühimme Defterleri varken artan iş yükü nedeniyle Mühimme Defterleri yalnız idari mevzularda alınan kararların kaydedildiği bir defter olarak ihtisaslaşırken halkın şikayetleri için ayrıca Şikâyet Defterleri adıyla yeni bir defter türü ortaya çıkmıştır. Bu defter türü bir yüzyıl işlev gördükten sonra Ahkam Defterleri adıyla bir başka defter grubu oluşturulmuştur. Dolayısıyla yerelde çözümlenebilecek pek çok meselenin bir üst merciiye taşınması bir bakıma devletin hantallaşması ve adli işleyişin daha da girift bir hal almasına yol açmıştır.

Sonuç olarak Erzurum Ahkam Defterleri'nde Tortum kazasına ilişkin izi sürülen kayıtlar 18. yüzyılın ikinci yarısında bölgenin sosyal, hukuki, ekonomik ve idari yapısına dair önemli veriler sunmaktadır. İmparatorluğun küçük bir parçası konumundaki Tortum ait olduğu siyasi teşekkülün yaşadığı problemlerin benzerlerini yaşamıştır. Çözüm noktasında sistemin elverdiği olanaklar bölge halkı tarafindan kullanılmış ve merkezi idarede gücü nispetinde olaylara çözüm getirmeye çalışmıştır.

\section{Kaynakça}

\section{Arşiv Kaynakları}

Devlet Arşivleri Başkanlığı Osmanlı Arşivi Bab-1 Âsafî, Divan-1 Hümâyûn Sicilleri Erzurum Ahkam Defterleri, 1,3,4,6,9.

\section{Araştırma ve İnceleme Eserleri}

AFYONCU, Erhan, "Defterhane”, TDVIA, C. 9, İstanbul 1994, s. 100-104.

AFYONCU, Erhan, “Zeamet”, TDVIA, C. 44, İstanbul 2013, s. 162-164.

AHISHALI, Recep, "Divan-1 Hümayun Teşkilatı", Osmanlı, C. 6, Ed. Güler Eren, Kemal Çiçek, Cem Oğuz, Yeni Türkiye Yay., Ankara 1999, s. 24-33.

AKGÜNDÜZ, Ahmet, İslam ve Osmanlı Hukuku Külliyatı: Kamu Hukuku, Osmanlı Araştırmaları Vakfi Yay., İstanbul 2011.

BARKAN, Ömer Lütfü, “Timar”, TDVİA, C. 12/1, MEB Yay., 1979, s. 286-333.

Başbakanlık Osmanlı Arşivi Rehberi, haz. Yusuf İhsan Genç, Mustafa Küçük vd., Devlet Arşivleri Genel Müdürlüğü Osmanlı Arşivleri Daire Başkanlığı Yayın Nu: 108 Başbakanlık Basımevi, İstanbul 2010.

DEMIR, Alpaslan, "Osmanlı Devleti'nde Yörükler ve Yerleşiklerin Kavgası: Kayıp Köyler Meselesi" Gazi Akademik Bakış, C. 11, S. 21, 2017, s. 15-31,

DEMIR, Alpaslan, Osmanlı Devleti'nde Vergilerin Göçlere Etkisi ve Kayıp Köyler Meselesi”, Dede Korkut'un İzinde 30 Yll Prof.Dr. Üçler Bulduk'a Armağan Türk Tarihine Dair Yazılar, Gece Kitaplığı, Ankara 2017, s. 441-465.

DEMIR, Alpaslan, Erzincanlı Göçmenler ve İskân Tarihi Açısından Önemi”, IV. Uluslararası Canik Sempozyumu Geçmişten Günümüze Şehir ve Çocuk, 15-17 Mayıs 2015, C. I, Samsun 2016, s. 403-408. 
DEMIR, Alpaslan, "Karahisar-1 Şarki'li Göçmenler ve İskân Tarihi Açısından Önemi”, INOCTE 2016, International New Tendencies Congress in Ottoman Researches, October 7-9, Sarajevo 2016, s. 57-68.

DEMİR, Alpaslan, "XV. Yüzyılın İkinci Yarısında Tokat Şehrinde Göçmenler", Tokat Sетроzуити 01-03 Kasim 2012, C. I, Tokat 2012, s.83-95.

DEMİR, Süleyman, “Osmanlı'da Kadılar ve Naipler”, Uluslar arast Sosyal Bilimler Dergisi, C. 1, S. 1, 2017, s. 28-37.

EMECEN, Feridun M., "Mufassaldan İcmale”, Osmanlı Araştırmaları, C.XVI, İstanbul 1996, s. 37-44.

EMECEN, Feridun M., "Osmanlı Divanının Ana Defter Serileri: Ahkâm-1 Mîrî, Ahkâm-1 Kuyûd-1 Mühimme ve Ahkâm-1 Şikâyet", TALID, C. 3, S. 5, 2005, s. 107-139.

ERDOĞAN ÖZÜNLÜ, Emine, "Osmanlı Devleti'nde Nüfus Artışı, Göçler ve Kaybolan Yerleşmeler (XVI-XVII. Yüzyıl)", Avrupa Tarihinde Türk Eli Doç. Dr. Gümeç Karamuk Armağanı, Hacettepe Üniversitesi Yay., Ankara 2017, s. 127-136,

ERDOĞAN ÖZÜNLÜ, Emine, "Osmanlı İskan Tarihine Dair Önemli Bir Kaynak: TimarRuznamçe Defterleri” Hacettepe Üniversitesi Edebiyat Fakültesi Dergisi, C. 33, S. 1, 2016, s. 141-155.

ERDOĞAN ÖZÜNLÜ, Emine, Ayntab Sipahileri/ Bir Osmanlı Sancağında Timarlı Sipahi Olmak (1530-1647), Berikan Yay., Ankara 2011.

GÜMÜŞÇÜ, Osman - ERDOĞAN ÖZÜNLÜ, Emine, "Osmanlı İmparatorluğunda İç Göç Aktörleri Olarak Çift-Bozanlar”, Amme İdaresi Dergisi, C. 49, S. 1, Mart 2016, s. 2956.

GÜMÜŞÇÜ, Osman, "Gözlemcilerin kaleminden Osmanlı Dönemi Yerleşmelerin Terk Edilmesi ve Kaybolması", Kitap Dostu Prof. Dr. Ali Birinci Armağanı, Polis Akademisi Yay., Ankara 2017, s. 479-502,

GÜMÜŞÇÜ, Osman-DEMIR, Alpaslan-ERDOĞAN ÖZÜNLÜ, Emine, Türkiye'nin Kayıp Köyleri, Yeditepe Yayınları, İstanbul 2020.

GÜNAY, Hac1 Mehmet, "Himâ”, TDVİA, C. 18, İstanbul 1999, s. 52-55.

GÜNAY, Ramazan, "Osmanlı Arşiv Kaynakları İçerisinde Ahkam Defterleri: Gelişim Seyri, Mutevas1 ve Önemi”, Süleyman Demirel Üniversitesi Sosyal Bilimler Dergisi, S. 11, 2013, s. 9-29.

İNALCIK, Halil, “Timar”, TDVİA, C. 41, İstanbul 2012, s. 168-173.

İNBAŞI, Mehmet, Osmanlı İdaresinde Tortum Sancağı (1549-1650), Yeditepe Yay., İstanbul 2008.

KÜTÜKOĞLU, Mübahat, “Mühimme Defterleri”, TDVİA, C. 31, İstanbul 2006, s. 520-523.

ÖZGER, Yunus, “XIX. Yüzy1l'da Tortum'un Nüfus Durumu”, Atatürk Üniversitesi Sosyal Bilimler Enstitüsü Dergisi, C. 8, S. 2, s. 113-128.

PAKALIN, Mehmet Zeki , "Mahzar”, Osmanlı Tarih Deyimleri ve Terimleri Sözlügü,, MEB Yay., C. 2, İstanbul 1993.

SAHILLIOĞLU, Halil, “Ahkam Defteri”, TDVIA, C. 1, İstanbul 1988, s. 550-551.

SAHİLLIOĞLU, Halil, "Bâd-1 Hevâ", TDVIA, C. 4, İstanbul 1991, s. 416-418 
SAHILLIOĞLU, Halil, "Resim”, TDVIA, C. 34, İstanbul 2007, s. 582-584.

TABAKOĞLU, Ahmet , “Tekalif”, TDVIA, C. 40, İstanbul 2011, s. 336-337.

YAŞAR, Hakan, II. Meşrutiyet'in İlanından Yunan Işsgaline Batı Anadolu'da Eşkiyalık (19081919), Ankara Üniversitesi Türk İnkılap Tarihi Enstitüsü, Yayınlanmamış Doktora Tezi, Ankara 2015.

YELEK, Kamil, Gasp ve İtlaf Bağlamında Hanefi Sorumluluk Hukuku, İstanbul Üniversitesi Sosyal Bilimler Enstitüsü Temel İslam Bilimleri Ana Bilim Dalı İslam Hukuku Bilim Dalı, Yayınlanmamış Doktora Tezi, İstanbul 2019.

YİĞİT, İlker, "İskândaki Kararsızlık: Doğal Afetler ve Kaybolan Yerleşmeler (XVI-XX. Yüzy1l Manisa-Konya Çevresi Örneği)", Hacettepe Üniversitesi Türkiyat Araştırmaları Dergisi, S. 26, Ankara 2017, s. 329-364. 


\section{Summary}

It is seen that Ottoman state rulers and intellectuals inosculated on the concept of justice as the main reference source for the healthy functioning of the state. In this regard, the main emphasis on the official documents such as justice, law, edict, etc., prepared in the name of the welfare of the people and sent from the center to the local authorities is on fair treatment of the reaya. The first authority to be applied for the provision of vitality and order, i.e. justice, in the Ottoman provincial administration is the office of the Kadi. If the problems cannot be solved by the hands of Kadi, the highest authority is the Divan-1 Hümayun, where the people take shelter in.

In addition to his administrative and military duties, Divan-1 Hümayun was also at the top of the legal system. The people who could not solve their problems locally had the right to apply directly to the Court of Justice (Divan-1 Hümayun). Decisions taken regarding the complaints discussed in the Divan-1 hümayun were initially recorded in the Mühimme Registers. With the increase in the number of complaints since 1649, only issues related to the functioning of the state were recorded in the Mühimme Registers and public complaints were registered in the books issued under the name of Complaint Books. Due to the intensity of the 18th century, it was changed once again in 1742 and such issues were recorded in the Ahkam Books, which are kept private to the provinces.

These books include complaints such as land, vineyards, gardens, households, corrals and pastures, highland-barracks and water use disputes, credit-to-pay litigation, tax disputes, issues related to inheritance, interest and trades complaints, foundation issues, problems with grooming/zeal and inflammation. These records provide important data in the context of institutions, societies and individuals with the structure of the Ottoman Empire in the fields of agriculture, finance, foundation, trade, internal security, social life, etc. during the time period in which the books were kept.

In this study, the provisions related to Tortum district in Erzurum province between 1742-1804 will be evaluated. In this study, the provisions related to the Tortum district are 25, including Erzurum Ahkam Book no. 1 (6 pieces), Erzurum Ahkam Book no. 3 (10 pieces), Erzurum Ahkam Book no. 4 (4 pieces), Erzurum Ahkam Book no. 6 (3 pieces), Erzurum Ahkam Book number 9 (2 pieces).

Complaints made to the center from Tortum district were discussed in The Divan-1 Humayun and the provisions for the solution were written in Ahkam notebooks. However, important data sources were used in the center when these provisions were issued. When the records in the books kept in Defterhane are examined, some statements stand out and provide clues about these data sources. These sources are the Timar Ruznamçe Register, Mufassal Tahrir Register, Foundation Register, İcmal Tahrir Registers, which are kept on timar/zeamet, taxation and taxes.

Whether the people from the governing or managed sectors in the Tortum district could not solve their problems locally, they did not hesitate to apply to the Divan-1 Hümayun. Although it is in a remote location from Istanbul, they have managed to bring their search for justice to the center. In doing so, it is seen that they follow different methods. These methods are to come to Istanbul and submit their cases to the Divan-1 Hümayun, to apply with a petition/petition, to write a collective petition and to send a letter. Based on the records in the Ahkam Registers, it can be said that reaya, timar owners, naib, trustee of paper, foundation trustees, villagers etc. Every segment of society has the opportunity to use the justice channels offered by the state and to complain.

In the provisions determined in Erzurum Ahkam Notebooks regarding Tortum District, it is seen that there are many problems in social, economic and administrative terms. Although it is a narrow-scale administrative unit, the events and tensions in the region are not very separate from those experienced in the whole state. The main problem is that these problems cannot be solved locally. For this reason, peasants, city dwellers, merchants, cavalrymen, janissaries, trustees etc. living in Tortum, social segments have brought their problems to the center.

Ahkam Registers have a similar quality to the Şeriyye Registers kept locally. The provisions of the Ottoman Empire's executive body, the Divan-1 Hümayun, as a higher court show the state's official opinion on legal disputes and its actual local responses. In the books, there are complaints in various fields from ordinary crimes to administrative crimes. In this direction, the complaints reaching the center from the Tortum district include issues such as the use of timar/zeamet lands, tax disputes, abuses regarding the use of groves, plateaus, barracks, land and water, extortion-banditry and inheritance sharing.

The records of the Tortum district in Erzurum Ahkam Registers provide important data on the social, legal, economic and administrative structure of the region in the second half of the 18th century. Tortum, which was a small part of the empire, experienced the same problems as the political organization to which it belongs. At the point of solution, the facilities allowed by the system were used by the local people and tried to solve the problems in terms of their power in the central administration.

\section{History Studies \\ www.historystudies.net}

